\title{
Analysis of the Relation Between and Impact of Public Service Media and Private Media
}

\author{
Prepared by \\ The Reuters Institute for Study of Journalism (RISJ) \\ University of Oxford

$\begin{array}{ll} & \text { REUTERS } \\ \text { UNIVERIIY OF } & \text { STUDY of } \\ \text { OXFORD } & \text { JOURNALISM }\end{array}$

For

The Ministry of Culture (Denmark)

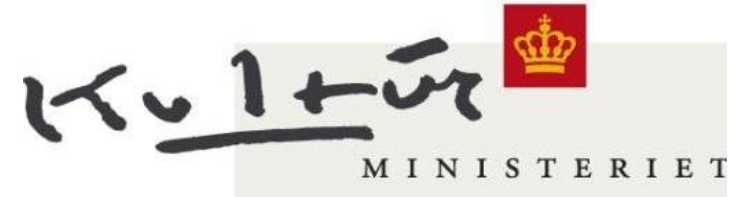


Prepared by

Rasmus Kleis Nielsen

Richard Fletcher

Annika Sehl

\& David Levy 


\section{Table of contents}

Opsummering af undersøgelsen og dens implikationer for danske forhold.............5

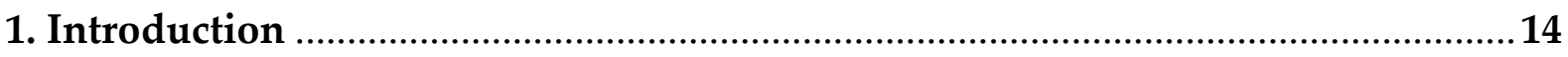

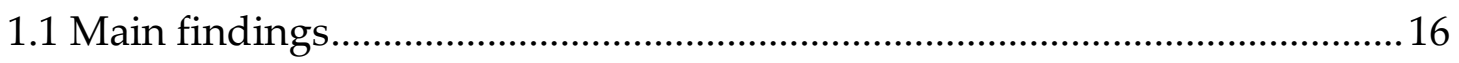

1.2 Mapping the research ................................................................................ 17

1.3 Relevance of the findings for Denmark …………………………………....2 20

1.4 Structure of the rest of the report................................................................... 20

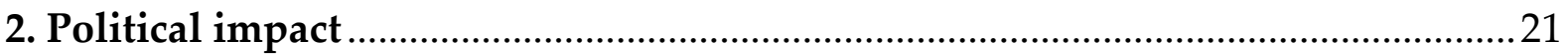

2.1 Public service media broadcast more news and current affairs programmes at peak times ................................................................................. 23

2.2 Public service media help increase knowledge of politics, current affairs,

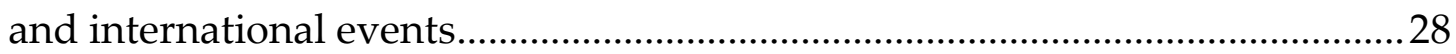

2.3 Public service media may increase propensity to vote ....................................35

Political impact -table of sources.............................................................................. 39

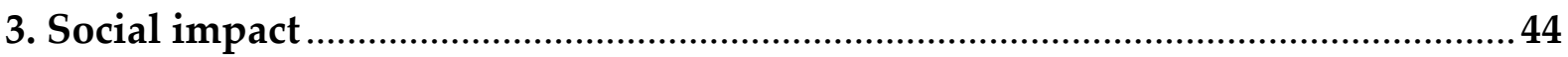

3.1 Some public service media achieve higher levels of audience satisfaction 45

3.2 Popular public service media are associated with social trust.......................50

3.3 Public service news consumption leads to more realistic perceptions of

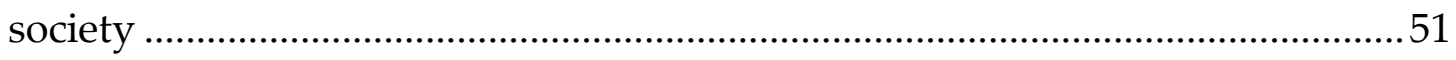

3.4 Public service media arrangements may help foster trust in TV ..................52

Social impact-table of sources........................................................................... 53

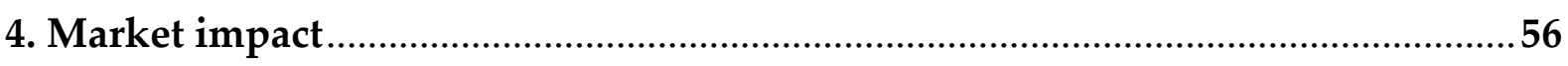

4.1 Public service media impact on private sector media ......................................57

4.2 Public service media impact on investments in original content .................65

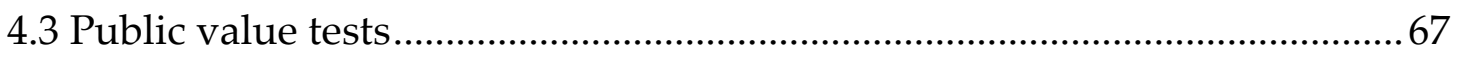

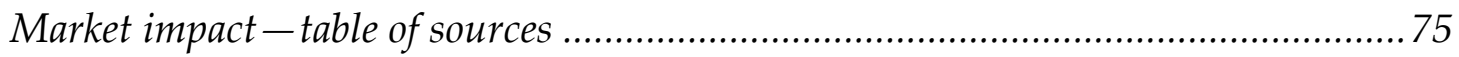

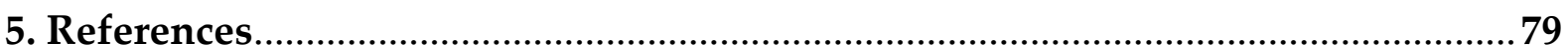

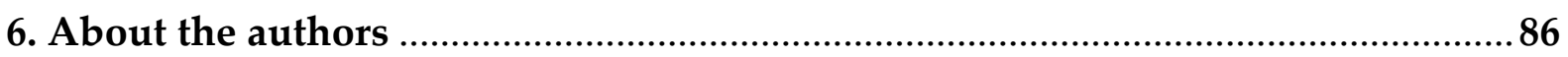




\section{Opsummering af undersøgelsen og dens implikationer for danske forhold (Danish)}

Formålet med denne rapport er at præsentere en metaundersøgelse af relevante studier af samspillet mellem public service-medier og private medier med henblik på disse mediers samlede bidrag til samfundets oplysning, udvikling og sammenhængskraft.

Rapporten fokuserer på at kortlægge den udenlandske litteratur med særlig fokus på studiernes relevans for danske forhold. Den engelske hovedrapport giver en oversigt over, hvad den eksisterende videnskabelige litteratur samt relevante offentlige og private undersøgelser fra forskellige interessenter har at sige om emnet. Denne danske opsummering præsenterer hovedresultaterne af undersøgelsen og diskuterer implikationerne for den danske situation. Rapporten beskæftiger sig kun med evidensbaserede undersøgelser, der giver en databaseret indsigt $i$ de ovenstående spørgsmål. Vi har styret uden om den omfattende litteratur, hvor forskellige forfattere giver udtryk for, hvad de tror og mener. Metaundersøgelsen (på engelsk) fokuserer altså på den eksisterende udenlandske evidensbaserede forskning, mens vi her desuden søger at relatere resultaterne til den danske situation.

Det mest slående resultat af vores gennemgang af mere end tusind videnskabelige og andre studier er, hvor lidt forskning og anden evidensbaseret, analytisk indsigt vi har i samspillet mellem public service-medier og private medier. Kun ganske få undersøgelser inkluderer begge typer af medier, og endnu færre analyserer deres samspil. Ydermere beskæftiger næsten al tilgængelig forskning sig med prædigitale medier. Der er altså ganske meget viden om, hvordan 1990'ernes medier fungerede, og betydeligt mindre viden om, hvordan 2010'ernes medier fungerer.

Rapporten og vores kortlægning afspejler i sagens natur den "availability bias", der eksisterer i den tilgængelige forskning, hvor der er en stærk tendens til at fokusere på forskellige medier hver for sig, hvor en stor del af forskningen er fokuseret specifikt på implikationerne af public service-medie-interventioner på markedet og kun bruger private medier som en form for grundlinje, i forhold til hvilken public service medier vurderes, og hvor der er meget lidt forskning i digitale medier.

Der er i Europa langt mere forskning i, om public service-medier på den ene eller anden måde er "bedre" end private medier, end der er specifikt i private mediers politiske, sociale, og markedsmæssige implikationer. Set i lyset af det pres, forskellige dele af branchen har været udsat for de sidste år, er det slående, hvor ofte private medier bliver taget for givet. Desuden er mange publikationer, der 
beskæftiger sig med medier, enten ikke af empirisk art eller ikke optaget af disse mediers politiske, sociale, og/eller markedsmæssige implikationer.

Vi gennemgår i rapporten i detaljer den omfattende forskning i public servicemediers forskellige bidrag, fordi denne viden er værdifuld i sig selv, og fordi den ofte indirekte inkluderer en vurdering af forskellene mellem implikationerne af forskellige former for medier.

Som en del af vores metaundersøgelse gennemgår vi både videnskabelig litteratur (med fokus på litteratur der har været underkastet fagfællebedømmelse/peer review) samt andre relevante undersøgelser normalt udført og/eller finansieret af forskellige former for interessenter (myndigheder, medieorganisationer etc.).

Vi vurderer løbende de enkelte studiers datagrundlag og metode samt den overordnede relevans for danske forhold. Vi identificerer, (1) hvor der er enighed om evidensbaserede konklusioner, (2) hvor der er uenighed, og (3) hvor der kun er lidt eller ingen relevant, evidensbaseret viden.

I vores gennemgang af den eksisterende forskning på området har vi haft særlig fokus på at identificere studier, der (a) belyser hvordan forskellige medietyper bidrager til og understøtter oplysning af borgerne, (b) ser på hvordan de bidrager til at sikre den samfundsmæssige sammenhængskraft og (c) undersøger den konkurrencemæssige og økonomisk effekt af samspillet mellem public servicemedier og private medier.

Vi har gransket hvert spørgsmål som en del af en bredere gennemgang af, hvad den eksisterende forskning har at sige om de politiske, sociale, og markedsmæssige implikationer af public service-medier, fordi dette er genstand for det meste af den foreliggende forskning.

Særligt med hensyn til (b) og (c) specifikt, og i bredere forstand (2) og (3), er den eksisterende forskning meget begrænset-særligt den uafhængige, fagfællebedømte forskning.

Fordi forskningen i flere af disse specifikke spørgsmål er meget begrænset, er rapporten struktureret omkring de bredere spørgsmål. I resten af rapporten gennemgår vi systematisk forskningen angående (1) politiske implikationer, (2) sociale implikationer og (3) markedsmæssige implikationer. Vi fokuserer på de vigtigste 36 videnskabelige og 16 andre undersøgelser, vi har identificeret fra de mere end tusind publikationer (tidsskriftsartikler, bøger, bogkapitler, rapporter m.m.), vi har gennemgået.

De fem vigtigste konklusioner fra vores gennemgang er: 
1. Trods megen skepsis over for mediernes rolle fra mange sider er der god grund til at tro, at de fleste indholdsmedier, både private og public service, trykte og elektroniske, netto leverer et positivt bidrag til samfundets oplysning og kan bidrage positivt til samfundets sammenhængskraft. Resultaterne på området er ikke entydige, men overvejende positive.

2. Det betyder ikke, at alle mediers bidrag til oplysning og sammenhængskraft er det samme. Et flertal af studier dokumenterer, at morgenavisernes læsere er markant mere velinformerede om samfundsforhold end andre, også når man kontrollerer for andre faktorer som alder, uddannelse, politisk interesse, etc. Resultaterne for kommercielt TV og tabloidaviser er blandede og tyder $i$ bedste fald på en mindre positiv effekt - i en del undersøgelser ingen positiv effekt. Resultaterne omkring dagblade er konsistente på tværs af en række undersøgelser og repræsenterer en evidensbaseret konsensus. Forskningen i kommercielt TV og tabloidaviser er mindre omfattende.

3. Et stort flertal af studier finder stærk evidens for, at public service-medier bidrager positivt politisk til samfundets oplysning, og nogen evidens for et positivt socialt bidrag, og finder desuden, at public service-medier på flere parametre har større effekt end de fleste private medier (med undtagelse af morgenaviser). Groft sagt tyder forskningen på, at morgenaviser har haft stor effekt på relativt færre læsere og public service-medier lidt mindre effekt, men på relativt flere brugere. Resultaterne omkring public service-mediers positive bidrag til folks viden om politiske forhold er ens på tværs af en række undersøgelser og udtryk for en evidensbaseret konsensus. Forskningen i sammenhængskraft og sociale implikationer er mindre omfattende.

4. Med hensyn til forskning i samspillet er der begrænset evidens for, at public service-medier har en negativ markedsmæssig effekt på private medier. Forskningen på området er mindre omfattende og næsten udelukkende udført af eller for interessenter. Nogle studier finder ingen effekt, enkelte studier en svag negativ effekt, og et enkelt studie hævder at have identificeret en positiv sammenhæng. Der er meget lidt uafhængig forskning på området, og der er ingen klar evidensbaseret konsensus.

5. Den eksisterende forskning beskæftiger sig næsten udelukkende med prædigitale medier, fjernsyn, radio, og trykte aviser. Vi har ikke identificeret relevant, publiceret forskning der direkte adresserer, hvad (a) eksisterende mediers digitale aktiviteter og/eller (b) rene digitale medier og servicers bidrag til samfundets oplysning og sammenhængskraft er. Det betyder, at vi ikke bare kan antage, at de ovenstående effekter - identificeret i forskning 
fokuseret på fjernsyn, radio, og trykte aviser - nødvendigvis er de samme, når det kommer til de samme medieorganisationers digitale udbud. Vi ved desuden meget lidt om udenlandske digitale medier og servicers politiske og sociale implikationer.

Samlet giver forskningen indtryk af, at mediernes samlede bidrag til samfundets oplysning, udvikling og sammenhængskraft afhænger af (a) et alsidigt og konkurrencepræget mediebillede, (b) hvor flere forskellige publicistiske medier investerer i originalt indhold og journalistik og (c) når et bredt publikum og formår at fastholde deres interesse. Uden alsidighed og konkurrence får folk færre valgmuligheder, og kvaliteten daler. Uden investeringer i originalt indhold og journalistik er der mindre at komme efter. Uden et bredt publikum og opmærksomhed vil det kun være et mindretal, der nyder godt at udbuddet.

I et internationalt perspektiv står Danmark stærkt på alle tre parametre (Albæk et al 2013, Newman et al 2015). I 2015 viste en international spørgeskemaundersøgelse, at 96 \% af alle danske internetbrugere regelmæssigt brugte nyheder, og at både avisbranchen (87\%) og de elektroniske medier (92\%) på tværs af deres forskellige tilbud formåede at nå langt de fleste danskere med nyheder mindst én gang om ugen (Newman et al 2015). Det er en bedre præstation end i fx Frankrig, Storbritannien, Tyskland og USA, og det er værd at tilføje, at danskerne i undersøgelsen ikke giver udtryk for højere interesse for nyheder end borgere $\mathrm{i}$ andre lande.

Tabellen nedenfor opsummerer hovedresultaterne af vores gennemgang af relevante undersøgelser.

\section{Opsummering af hovedresultater fra metaanalysen af eksisterende undersøgelser}

Vi har gennemgået over tusind videnskabelige studier og interessentstudier og præsenterer nedenfor en gennemgang og nærmere evaluering af de i vores øjne 36 vigtigste videnskabelige og 16 vigtigste andre studier. Disse studier er udvalgt, fordi de er de mest relevante for de stillede spørgsmål, relevante for den danske kontekst, og er de mest indflydelsesrige med hensyn til, hvor mange andre publikationer af forskellig art der trækker på dem.

Hovedresultaterne af vores gennemgang og metaanalyse er:

- En omfattende forskning i politiske implikationer finder, at public service-medier (a) publicerer flere nyheder end sammenlignelige kommercielle medier, (b) har en positiv indvirkning på befolkningens generelle viden om politik, og (c) en inkrementelt positiv virkning på politisk deltagelse. Der er en høj grad af 
konsensus om disse resultater. Forskningen identificerer nogle af de samme positive effekter for visse private medier, særligt morgenaviser, og forskningen tyder på, at disse stadig er hovedproducenter af originale nyheder. Der er igen en høj grad af konsensus om disse resultater. Resultaterne for tabloidaviser og kommercielle TV-/radiostationer er mere blandede, og her hersker ingen konsensus. Vi har analyseret $i$ alt 23 videnskabelige og 4 interessentstudier inden for dette område.

- Forskningen i sociale implikationer er langt mindre omfattende og giver ikke grundlag for at identificere en evidensbaseret konsensus. Men resultaterne tyder på, at public service-medier leverer et positivt socialt bidrag med hensyn til tillid, viden om samfundet og alsidighed i mediebilledet. Igen er flere af disse effekter også associeret med morgenaviser, men ikke systematisk med andre private medier. Der er ingen relevant forskning om social sammenhængskraft. Relateret forskning i USA præsenterer modstridende resultater og er ikke nødvendigvis relevant $i$ en dansk sammenhæng. Vi har analyseret $i$ alt 11 videnskabelige og 5 interessentstudier inden for dette område.

- Forskningen i de markedsmæssige implikationer er stort set ikkeeksisterende i den videnskabelige litteratur og næsten udelukkende bedrevet af forskellige interessenter. Resultaterne af interessentundersøgelser understøtter ofte disses politiske prioriteter. Overordnet finder disse studier begrænset eller ingen evidens for, at public service-medier har en negativ effekt på det samlede mediemarked. Men den begrænsede forskning på området samt forskningens ophav betyder, at der ikke kan identificeres en evidens-baseret konsensus fra uafhængig forskning. Vi har analyseret $i$ alt 2 videnskabelige og 7 interessentstudier inden for dette område. (Dertil gennemgår vi forskellige public value test-systemer.)

Samlet set viser forskningen på området altså stærk evidens for, at public service-medier og morgenaviser har en positiv politisk betydning, nogen evidens for, at de har en positiv social betydning, og blandede resultater med hensyn til andre private mediers politiske og sociale effekt. Der er begrænset evidens for, at public service-medier skulle påvirke private medier negativt.

Det er vigtigt at understrege, at forskningen på området overordnet set må betegnes som begrænset, og at der er flere spørgsmål, hvor der kun foreligger ganske få evidensbaserede studier og derfor ikke er mulighed for at identificere en konsensus. Fraværet af evidens afspejler i flere henseender nok mere fraværet af forskning end fravær af effekt.

Ydermere er den altovervejene del af den eksisterende forskning på området - både fra videnskabelig side og fra andre - primært fokuseret på prædigitale medier. Kun ganske 
få studier dækker digitale medier, trods deres åbenlyse vigtighed. Resultater af forskning i $\mathrm{t} \mathrm{v}$, radio, og trykte aviser kan ikke nødvendigvis generaliseres til et forandret mediebillede, særligt fordi mange af de underliggende antagelser (om begrænset medieudbud, "captive audiences", og relativt klart definerede platformspecifikke separate markeder) ikke længere er gyldige.

Det er allerede klart, at udviklingen af et stadigt mere digitalt medie-billede har forandret, hvordan både private (Newman et al 2015) og public service-medier (Sehl et al 2016) fungerer, og hvordan de spiller sammen med udenlandske aktører.

Der er desværre næsten ingen forskning i, hvad konsekvenserne er.

\section{Forskningen, vi har gennemgået, er i overvejende grad fra lande, der er} sammenlignelige med Danmark, altså stabile højindkomstdemokratier med en lang tradition for stærke private medier og licencefinansierede uafhængige public service-medier og høj internetbrug.

Særligt små nordvesteuropæiske lande så som de nordiske lande og Benelux - i overvejende grad karakteriseret ved relativt små mediemarkeder og en grad af sprogbarriere for direkte konkurrence med internationale spillere - er velrepræsenteret i forskningen. Dertil er Storbritannien og Tyskland genstand for omfattende forskning. De to sidste har mange træk til fælles med Danmark, men er langt større markeder.

Overordnet vurderer vi, at det meste af den forskning, vi gennemgår i rapporten, er relevant for danske forhold og langt mere relevant end forskning udført i en ganske anden kontekst som fx USA, Sydeuropa, eller Central- og Østeuropa.

Men det er vigtigt at understrege, at der er mange områder og spørgsmål, hvor der kun er lidt eller ingen evidensbaseret viden, eller hvor der kun er sporadisk og ikke-repliceret forskning, som kun leverer et svagt grundlag for at drage bredere konklusioner.

Fraværet af videnskabelig dokumentation for effekter (hvad enten positive eller negative) afspejler altså ofte fraværet af relevant forskning, hvilket ikke nødvendigvis er det samme som fraværet af effekter.

Ydermere er det slående, at næsten alle de undersøgelser, vi har identificeretselv de nyeste, og uanset om de er fra forskere eller interessenter-udelukkende fokuserer på prædigitale medier og næsten aldrig diskuterer digitale medier.

Selvom digitale medier i 2016 udgør en af de vigtigste medieplatforme i mange henseender (og i mange lande), er vores evidensbaserede indsigt i konsekvenserne - både for borgerne og for samspillet mellem forskellige medier - desværre 
nærmest ikkeeksisterende. I fraværet af relevant forskning er det fristende at generalisere fra eksisterende undersøgelser af fjernsyn, radio m.m., men selvom disse undersøgelser generelt sandsynligvis stadig har platformspecifik gyldighed, giver de i mindre og mindre grad indsigt i mediebilledet som helhed. Fremtiden er altså, som sædvanlig, svær at spå om.

I lyset af metaundersøgelsens dokumentation for, at både avislæsning og public service medie-brug har positive politiske og sociale implikationer, og fraværet af klar evidens for, at public service-medier har en negativ effekt på private medier, er situationen i dagens Danmark umiddelbart opmuntrende.

Spørgsmålet er, hvad tidens hastige forandring i mediebilledet betyder for mediernes samspil og deres politiske, sociale, og markedsmæssige implikationer.

Groft sagt er det klart, at en 60-årig dansker, der ser og hører lidt fra DR og TV 2 hver aften, læser det lokale dagblad om morgenen og indimellem måske en af de landsdækkende aviser, får meget, alsidig og vigtig information. Det er imidlertid også klart, at færre og færre, specielt under 60, har sådanne medievaner. Både aviser og public service-medier har vundet et betydeligt publikum online, men deres traditionelle udbud er eroderet hastigt, først papiraviser og nu i stigende grad fjernsyn (DR Medieforskning 2016, Nielsen and Sambrook 2016). Folk har adgang til meget information, særligt online, men de fleste bruger nyhedsmedierne mere selektivt og sporadisk end tidligere. Vi er på vej fra et mediebillede, hvor de mange fik en del nyheder, mod et mediebillede, hvor de få opsøger et væld af nyheder og de fleste relativt få nyheder.

Forandringerne undervejs i Danmark som verden over-og desværre kun i ringe grad dokumenteret og analyseret i forskningen - stiller mindst tre store spørgsmål angående mediernes politiske, sociale, og markedsmæssige implikationer i fremtiden. For hvert spørgsmål præsenterer vi også en hypotese for, hvor udviklingen er på vej hen. Disse hypoteser er i sagens natur ikke evidensbaserede, men baseret på de trends, vi generelt ser i medieverdenen.

\section{- Hvad er de politiske implikationer af nyheders plads i et digitalt} mediebillede? Nyheder og samfundsstof har historisk været en central del af både aviser og public service-mediers udbud og er det fortsat på diverse digitale platforme, hvor både aviser og public service-medier som sagt når et bredt publikum. Men andelen af folks digitale mediebrug, der er nyhedsrelateret, er begrænset. Branchekilder som comScore anslår fx, at omkring 4 procent af den tid, folk i USA bruger online, er nyhedsrelateret (comScore 2016). Det er betydeligt mindre end for fjernsyn og papiraviser. Forandringen er drevet af borgernes præference for andre former for indhold 
og servicer tilgængeligt på de digitale platforme. Det er muligt, at mere effektiv, individualiseret, og selektiv nyhedsbrug via digitale platforme giver borgerne den viden om samfundet, de føler, de har brug for. Men vi ved det ikke, og man kan næppe bare antage, at positive politiske og sociale implikationer associeret med at læse papiravis eller se TV-nyheder i en halv time dagligt også er associeret med de i gennemsnit cirka 6 minutter, danskerne i følge gemiusAudience i 2015 brugte dagligt på de landsdækkende dagblades hjemmesider, eller de cirka $3 \frac{1}{2} 2$ minut, de brugte på de landsdækkende public service-mediers hjemmesider (Kulturstyrelsen 2015). (Til sammenligning har Facebook i 2015 estimeret, at deres brugere i gennemsnit bruger 46 minutter om dagen på det sociale netværk.) Et stort flertal af danskerne opsøger stadig nyheder, også på diverse digitale platforme, men de fleste, særligt de yngre, bruger mindre tid med nyhedsstoffet og finder tilsyneladende andet indhold og andre servicer mere interessant og relevant for dem. Hvad disse andre servicer betyder politisk og socialt, er desværre ikke dokumenteret i den eksisterende forskning. Vores hypotese er, at Danmark kommer til at se en stigende polarisering mellem de mest nyhedsinteresserede - som vil opsøge indhold fra både private medier og public service-medier, både direkte og via forskellige digitale mellemmænd som søgemaskiner og sociale medier - og en voksende gruppe med stadigt mere selektiv og sporadisk nyhedsbrug, som vil være en mindre kommercielt attraktiv målgruppe for private nyhedsmedier og stadigt sværere at nå for public service-medier.

\section{- Hvad er de sociale implikationer af mere ulige mediebrug, drevet af ulige} interesser? Skridtet fra et mediebillede med et begrænset antal valgmuligheder til et med et nærmest ubegrænset antal valgmuligheder (særligt online) betyder, at folk i højere og højere grad udvikler medievaner der afspejler deres personlige præferencer og umiddelbare omgangskredsspecifikt synes forskellen mellem dem, der er mest interesserede i nyheder og samfundsforhold (og ofte er veluddannede), og dem, der er mindre interesserede i nyheder og samfundsforhold, at være stigende. Det er ikke udtryk for, at folk i dag er mindre interesserede i nyheder og samfundsforhold end folk var tidligere. Det er blot udtryk for, at de har mere (og mere og mere) at vælge imellem. Der er stor og stigende forskel på, hvordan folk med forskellige grader af interesse for nyheder og samfundsforhold bruger medier, måske blandt andet fordi mange almindelige mennesker har svært ved at relatere til meget af nyhedsstrømmen. I lyset af metaundersøgelsens dokumentation for den positive sammenhæng mellem nyhedsmediebrug og viden om 
samfundsforhold, politisk deltagelse, etc. er spørgsmålet om medier, der historisk har udlignet vidensforskelle og bundet folk sammen, vil gøre det samme i fremtiden, og hvad brugen af forskellige digitale medier har af politiske og sociale implikationer. Vores hypotese er, at de fleste private indholdsmedier i højere og højere grad vil baserede deres forretningsmodel på produktdifferentiering målrettet mod bestemte nicher (og ikke et massepublikum), at public service-medier får sværere og sværere ved at samle et bredt publikum om fælles indhold og oplevelser, og at fællesnævnerne i danskernes mediebrug i stigende grad bliver udenlandske digitale tjenester, som servicerer et bredt publikum med stadig mere personligt tilpasset indhold.

- Hvad er de markedsmæssige implikationer af et stadig mere digitalt mediebillede præget af forandret konkurrence mellem private og public service-medier og stadig større rolle for populære udenlandske servicer? Den eksisterende forskning giver ikke grundlag for at tro, at public servicemedier generelt har en negativ indvirkning på private medier inden for et givet nationalt marked. Men denne forskning har generelt fokuseret på platformspecifikke markeder som fjernsyn eller radio, og kun i begrænset omfang analyseret samspillet på nettet. Generelt bruger danskerne flere og flere penge på medierelaterede udgifter, og annoncemarkedet forsætter med at vokse (Kulturstyrelsen 2015). Men både forbrug og annoncer er overordnet på vej væk fra danske producenter af nyheder og originalt indhold og på vej mod hardware, adgang til telekommunikation (mobil, bredbånd etc.) og betalings-TV (i stigende grad SVOD) samt populære udenlandske servicer. Siden 2013 er over halvdelen af annonceomsætningen på internettet $\mathrm{i}$ Danmark gået til udlandet (Kulturstyrelsen 2015). Vores hypotese er, at denne udvikling vil forsætte og give danskerne adgang til stadig mere avanceret og attraktivt digitalt indhold og servicer fra udlandet, samtidig med at mange indenlandske private indholdsmedier og public service-medier kommer til at spille en relativt set mindre rolle med hensyn til deres andel af danskernes samlede mediebrug og med hensyn til mediesektorens samlede omsætning. 


\section{Introduction}

The purpose of this report is to map relevant academic and stakeholder (industry/regulatory) research on the relation between public service media and private sector media with regard to their political impact, social impact, and market impact.

The report maps what we know, where there is disagreement, and what we do not know, with a special emphasis on implications for Denmark.

The review covers relevant academic research (defined as research published after peer review and/or independent research published by academics) as well as a mapping of publicly available stakeholder research - normally commissioned and/or conducted by various stakeholders including governments, media regulators, public service media organisations, or private sector media organisations.

We review only evidence-based research, and not the more voluminous literature laying out different views of what public service media should do, might do, etc. We focus on research from the last 10 years in light of the ongoing dramatic changes in the media environment, and on research dealing with Northern Europe and Western Europe, countries that are culturally and politically relatively similar to Denmark, and where the media historically has had a similar mix of strong private sector media and independent public service media.

The academic research we have reviewed overwhelmingly focuses on assessing the impact of public service media compared to a baseline of private sector media, with little independent scrutiny of their distinct, independent impact. The stakeholder research is all concerned with the impact of public service media.

The underlying assumptions in the academic research are twofold. First, there is a voluminous literature from the United States highlighting that some kinds of private sector media under some conditions contribute politically by allowing citizens to become more informed about public affairs, socially by encouraging social cohesion, and to the market through value added, jobs created, and private provision of public goods such as hard news (see e.g. Norris 2000; Hamilton 2004; Lowrey et al. 2008). ${ }^{1}$ Second, because many of these positive contributions are seen as potentially in conflict with the commercial motives of private sector media, researchers have been

\footnotetext{
${ }^{1}$ Under other conditions, private sector media are seen as driving a "spiral of cynicism" (Capella and Jamieson 1997) and undermining social capital (Putnam 2000) through sensationalist and divisive content produced forprofit. On balance, the scholarly consensus tends to see the positive impact of private sector media, in particular news media, as slightly outweighing their negative impact in terms of political and social participation (Norris 2000). The United States literature is too voluminous to review here and focuses on a country that is very different from Denmark culturally, politically, and in terms of its media system.
} 
interested in assessing whether public service media, with their very different funding structures, legal obligations, and hence motives, have different implications.

The academic research we review here thus recognises that private sector media can make a significant positive contribution to society in many different ways, but largely takes this for granted, while focusing attention on the specific impact of public service media and the potential difference in impact between private sector media and public service media. We do not believe one can simply take private sector media, or their positive contribution to society, for granted, especially in light of the ongoing transformation of the media environment. The fact that some private sector media have throughout the 20th century made major investments in, for example, domestic original content and news journalism does not mean we can simply assume they will have the means and motives to do so in the 21st century. But as our task is to review existing research, we have structured the report in line with the texture of the research that exists in Europe, which overwhelmingly deals with public service media and their impact. Indirectly, this research also gives some indication of what we know about the impact of private sector media.

As part of the review, we summarise the findings of key studies and discuss the strength of the evidence it is based on as well as the strength of the analytical and methodological approach adopted. This enable an overall evaluation of the robustness of the conclusions.

Furthermore, the meta-analysis provides a map of:

- where existing research points to an evidence-based consensus;

- where there are disagreements and conflicting conclusions; and

- where there is little or no evidence-based knowledge.

The primary areas of focus are:

1. The political impact of various combinations of public service media provision and private media provision on the general population's political knowledge and political participation.

2. The social impact of various combinations of public service media provision and private media provision on the general population's relation to society more widely.

3. The market impact of various forms of public service intervention for the overall media system in terms of impact on private media, on content investment, and on diversity of provision. 


\subsection{Main findings}

Altogether, we have examined more than a thousand academic and stakeholder studies. Here we present a closer review focusing on the most relevant 36 academic publications and 16 industry publications. Our findings are:

- There is a significant amount of research that assess the political impact of public service media. We review 23 academic studies and 4 stakeholder studies. The evidence-based consensus in this area is based on a growing number of studies by different researchers using different kinds of data and approaches, with the majority concluding that public service media have a net positive impact on (a) the amount of hard news produced and (b) levels of political knowledge, and, by extension, they may also (c) incrementally increase political participation. It is important to note that this research often also find the same positive impact for some forms of private sector media, most notably morning newspapers, and that research still suggests that especially newspapers produce the largest proportion of news output in most countries.

- There is less research on the social impact of public service media. We discuss 11 academic studies and 5 stakeholder studies that examine public service media impact on social trust, broader knowledge about society (beyond politics), and the degree to which media content reflects the diversity of society itself. The studies reviewed tend to point towards a net positive impact of public service media when it comes to trust, knowledge, and diversity. But the limited number of studies means that there is little or no replication and hence no basis for identifying an evidence-based consensus on the social impact of public service media. American research has suggested that private sector media can help increase social cohesion, but other researchers argue that media undermine social capital. There is no evidence-based consensus in this area.

- There is little research that assesses the market impact of public service media. There are very few academic publications on this subject, and most of them are of limited relevance when it comes to assessing the likely market impact of public media, specifically in Denmark, in the contemporary media environment. The most robust research studies carried out in this area are funded by stakeholders, including government agencies, public service media organisations, and private sector media organisations (and in the latter two cases findings tend to support the funders' political priorities). We review 2 academic studies and 7 stakeholder studies. On the 


\section{whole, existing studies provide little evidence for a negative market} impact of public service media upon domestic private sector media. But the limited number of studies and the dearth of independent research means there is no clear evidence-based consensus.

The academic and stakeholder research reviewed thus provides strong evidence that public service media have a positive political impact, some evidence that public service media have a positive social impact, and little evidence that public service media have a negative market impact. ${ }^{2}$ Similar positive political and social impact is ascribed to some types of private sector media, most importantly morning newspapers. But there are many areas where we have found little evidence-based research, or only individual studies with no replication and/or no comparative dimension across different contexts. The volume of research varies by topic, with little academic, independent research on market impact. The limited research on some issues means that one cannot assume that the absence of findings is evidence of the absence of impact (whether negative or positive). In most cases, the absence of findings simply reflects the absence of research.

Existing research overwhelmingly focuses on broadcasting, and sometimes include printed newspapers, but pays little systematic attention to online media. We would caution that one cannot take for granted that findings from broadcast and print media necessarily transfer to digital media. This applies equally to work on political impact, social impact, and market impact, as all tend to operate with assumptions derived from an earlier, low-choice media environment that may be less appropriate for today's high-choice environment. It is clear that it is not only private sector media that are being impacted by this structural change: so are public service media. Digital media has long since overtaken print as a source of news in most high-income democracies (see e.g. Newman et al. 2015) and one recent study found that more citizens rely on social media than public service media for online news in 5 out of 6 European countries studied (Sehl et al. 2016).

\subsection{Mapping the research}

The report is based on an extensive review of published academic and industry/regulatory evidence-based research in English, German, and the Scandinavian languages. As noted, because of the nature of the existing research, we have focused on a systematic mapping of work on the impact of public service

\footnotetext{
2 The studies reviewed assess only effect, not efficiency, and some focus only on the impact of public service provision specifically, not what the net impact might be, taking into account interactions with private sector media and other players.
} 
media, which indirectly sheds light also on private sector media and the relations between public service media and private sector media.

The academic literature on public service media is voluminous. Much of it consists, however, of what Stephen Cushion has described as "viewpoints on the legalistic or policy-related condition of state or public service media" (Cushion 2012, p. 6) or essays offering more general viewpoints arguing for or against particular conceptions of what public service media ought to do. Such writings are concerned with assessing the mission and purpose of public service media in normative terms, or with analysing the development of institutional features such as role and remit, funding structures, and governance over time.

While interesting, this literature provides little or no basis for an evidence-based assessment of the impact of public service media or their relationship with private sector media.

In terms of evidence-based analysis of the political, social and market impact of public service media, the academic literature is more uneven. There are a significant number of recent publications on political impact, some studies of social impact, but very few academic studies of market impact. Stakeholder research funded by government, industry, and/or regulators has the opposite profile, with little work assessing political and social impact, but some work assessing market impact. Some of the stakeholder research is intellectually robust, and we discuss examples of it below, but - without questioning the integrity of those involved in conducting it-it is worth noting how frequently stakeholder research presents conclusions well aligned with the political positions advocated by the funder(s). Especially when it comes to market impact, there is a real need for more independent research.

For the review, we collected academic publications through a systematic literature search process guided by the University of Oxford library service, using the International Bibliography of the Social Sciences (IBSS). The IBSS is a comprehensive database that contains bibliographic information from an international selection of scientific publications (including over 2,600 journals covering over 100 countries and languages) in the fields of economics, political science, media/communications research, sociology, and anthropology. Our search covered the period from 1 January 2005 to 15 May 2016, to capture the most up-to-date research.

In the first stage of our review, we purposely used broad search terms to avoid excluding any potentially relevant sources. Specifically, we searched for the terms 'public service media' OR 'public service broadcast" OR 'public media' OR 'public broadcast $^{* \prime}$ OR 'PSB' in the title, abstract or subject heading of a publication. This procedure resulted in 401 matches, of which 323 were peer-reviewed publications. 
We have reviewed all titles and abstracts and, where relevant, the pieces in their entirety. We finally selected those publications (journal articles and books) that involved empirical studies on the political, social, or market impact of public service media. In addition, the German search terms 'öffentlich-rechtlich' OR 'ARD' OR 'ZDF' were used for the same search in order to ensure we captured relevant German sources in the database. Furthermore, we have reviewed all issues of Media Perspektiven (a research journal published by the German public service media organisation ARD) from 2005 to 2016 to identify relevant articles not indexed in IBSS. We reviewed 797 articles in German, including 176 dealing specifically with public service media. Most were not directly relevant for the report, but we discuss the most important ones below. Furthermore, we supplemented our formal search strategy with a series of informal searches using Google Scholar, in order to verify our results from IBSS and identify those sources published in the small number of relevant journals not included in the IBSS database. Beyond this, we have included a few additional sources as well as relevant stakeholder publications that were not listed in the database, selected after consultation with academic and industry experts.

This process produced a final tally of 36 academic publications and 16 pieces of stakeholder research selected for closer scrutiny. Much of the research is very strong, but overall it is important to note that the review presented here, like any metaanalysis, necessarily reflects the overall weaknesses of the field as a whole, which includes a publication bias towards publishing positive results (but not null results), an availability bias that comes with the overall greater interest in and emphasis on public service media (perhaps a version of what has been called 'white hat bias'), and an overwhelming focus in the research on broadcast media and to some extent newspapers over digital media, despite their obvious and increasing importance.

We review the findings under the three headings of political impact, social impact, and market impact below, summarise the studies discussed, and list all sources under references.

Given the role and remit public service media are given in many countries, the public value it is hoped they will deliver, the adverse consequences some stakeholders fear they have for private sector media, and the estimated annual investment of about $€ 16.6$ billion in public service provision across Europe, what we do not know about the impact of public service media, especially in a digital environment, is at least as striking as what we do know. 


\subsection{Relevance of the findings for Denmark}

Generally, the research reviewed underlines that the political, social, and market impact of public service media is context- and content-dependent, and thus depends on the specific market particular public service providers operate in and the specific forms of public service they provide. Results from North America or Southern Europe are thus not necessarily relevant for understanding Northern Europe, just as results even from contextually similar countries (like the Nordic countries) may be contingent on the specific services provided in each case. In the Danish summary above we discuss the likely implications of our findings for the Danish context and outlined questions moving forward.

The majority of the studies we discuss below focus on countries that are comparable to Denmark in terms of being (a) high-income stable democracies, (b) with a long tradition of public service provision, (c) historically strong private sector media, and (d) high levels of internet use. Some of the studies, however, deal with countries like Germany and the United Kingdom, which are far larger domestic markets, and/or with English-language markets with greater degree of spillover from international players, and other studies deal with countries like the United States, which are contextually very different from Denmark, or with public service providers like RAI in Italy, which are very different from those found in Denmark.

Almost all the studies reviewed focus wholly or mostly on the impact of public service broadcasting, often specifically television broadcasting. Very few academic and/or stakeholder studies focus on the impact of public service provision online. This is clearly a major lacuna in both the academic and stakeholder research, as digital media by now account for a large share of overall media use and a large share of the overall media market in most high-income democracies (e.g. Meeker 2015; Newman et al. 2015), and generally operate in ways that are different from legacy media and are deeply shaped by large international players including search engines, social media, and video-on-demand providers which are not systematically considered by any of the studies we review here.

\subsection{Structure of the rest of the report}

The rest of the report proceeds as follows. First, we review the most relevant studies examining the political impact of public service media. Second, we review the most relevant studies examining the social impact of public service media. Third, we review the most relevant studies examining the market impact of public service media. 


\section{Political impact}

Academic research on the political impact of public service media is relatively well developed. Whereas stakeholder research in this area has tended to focus on measures of use (audience share, etc.) and user satisfaction treated as proxies for impact, academics have developed more ambitious research designs to assess actual impact. We review 23 academic studies and 4 stakeholder studies below.

Much work in this area is based on comparative designs, often involving one or more Scandinavian countries in the sample and with most case countries being highincome democracies, many in western and northern Europe. Many of the findings are therefore likely to be broadly applicable in the Danish context as they generally include one or more comparable countries.

The main areas of focus in this line of work is on the impact public service media have in terms of (a) the provision of hard news in a media system, (b) how knowledgeable people are about politics in a given country, and (c) how involved people are in political processes.

In each area, there is a high degree of consensus in the academic literature. Several studies from different teams of researchers have found that (a) public service media devote more time to news and current affairs than most private sector media and tend to focus more on 'hard' news (such as international affairs, politics, and economics); (b) that people in countries with public service media-in particular independent, relatively well-funded, and popular public service media-generally know significantly more about politics than people in countries with weak or no public service media; and (c) that public service media may help increase electoral turnout (there are fewer studies in this area).

In each area, the difference between public service media and private, commercial broadcasters is generally pronounced, whereas some other private media, like morning newspapers (sometimes referred to as broadsheets or upmarket newspapers), are found to have many of the same positive political impacts, sometimes having a bigger impact (even if their research is more limited).

The research reviewed in this area is mostly based on content analysis and/or crosssectional surveys, often deployed in comparative designs involving multiple countries. These designs are generally solid, and the high degree of consistency in findings across multiple studies from different research teams and covering different countries suggests that the results are robust, even though they are rarely based on stronger designs such as panel surveys or experiments. 
Box 1 summarises the key findings from the reviewed research. Below, we discuss main points from a selection of the most important studies in greater detail. The table at the end of the chapter summarise the methods and conclusions of the studies discussed.

\section{Box 1: Political impact-key findings from existing research}

Consistent and replicated findings

- Public service media tend to broadcast more news and current affairs programmes at peak times, and proportionally more hard news. In many cases, this creates media environments where citizens have better opportunities to become informed.

- As a direct result, both individual exposure to public service media newsor living in a public service oriented media environment-is associated with increased knowledge of a variety of hard news topics, including politics, current affairs, and international events.

Findings from a limited amount of existing research

- Increased exposure to public service media news and generally increased political knowledge may increase individual propensity to vote, with national voter turnout rates higher in countries with public service oriented media systems.

Though not always made explicit, there is an implied chain of causation that links these three findings. It can be summarised as follows:

PSM broadcast more hard news, and more hard news at peak times

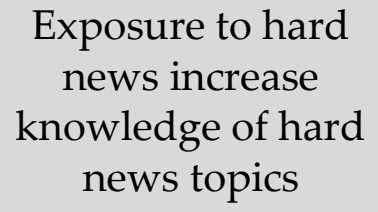

Exposure to hard news increase knowledge of hard news topics

Increased knowledge increases propensity to vote

Some studies address only one of the above, but most speak to at least two links of this causal chain. However, given that the strength of the evidence for each claim varies, we will examine them independently. As such, some studies are referred to repeatedly in order to comply with this structure. 


\subsection{Public service media broadcast more news and current affairs programmes at peak times}

Several studies have shown that public service media across different countries and contexts tend to broadcast more news and current affairs programmes at peak viewing times than commercial stations do, and as such, reach larger audiences with their news output (Aalberg et al. 2010; Aalberg \& Curran 2012; Esser et al. 2012). This difference is usually explained in terms of the fact that commercial broadcasters are incentivised to show popular entertainment programmes during peak hours in order to generate increased advertising revenue, whereas public service media are required not only to entertain, but also to educate and inform. Though in some cases commercial stations may produce more news output in total, several studies have found that public service media tend to broadcast a larger proportion of hard news (de Vreese \& Boomgaarden 2006; Curran et al. 2009; Iyengar et al. 2010; Aalberg et al. 2013). Despite this, it is less clear that public service oriented media systems always offer the best 'information opportunities' more generally, given that even within Europe, public service media vary significantly (Esser et al. 2012). Generally, researchers tend to find the media systems that combine strong private sector media with well-funded and politically independent public service media provide the best political information environments (Albæk et al. 2013).

Aalberg et al. (2010) examined the output from the four most-watched television stations in five European countries (the United Kingdom, Belgium, Netherlands, Sweden, and Norway) and the United States during the 20-year period from 1987 to 2007. Based on analysis of TV schedules, they found that in all six countries public service media devoted more airtime to news and current affairs programmes than commercial broadcasters during peak hours (see Figure 1).

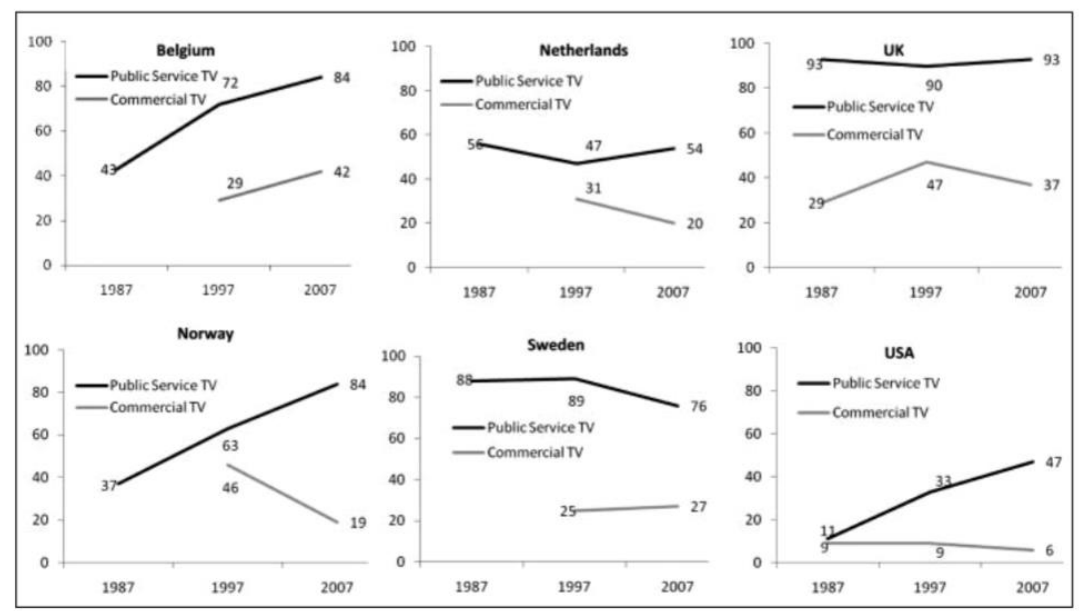

Figure 1: Supply of news and current affairs during peak hours on public service TV and commercial TV, 1987-2007: average minutes per day (Aalberg et al. 2010). 
For example, in 2007, the Swedish public service media organisation SVT broadcast an average of 76 minutes per day of news and current affairs during peak time, compared to 27 minutes on TV4 (a commercial station).

Aalberg et al. (2010) also made comparisons in terms of the media system in each country, based on classifications partly informed by the role and influence of public service media. In the five European countries they studied, which are characterised by strong public service media and comparatively low levels of commercialisation, the supply of news and current affairs programming increased from 1987 onwards. In contrast, the more heavily commercialised system in the United States reduced its news and current affairs output during the same time period. In the United States, though the average minutes per day devoted to news and current affairs was actually higher than in any of the European countries, most fell outside peak viewing times, reducing the total amount of attention paid to it, and took the form of local news, which the authors claimed is predominantly made up of soft news coverage (see Figure 2).

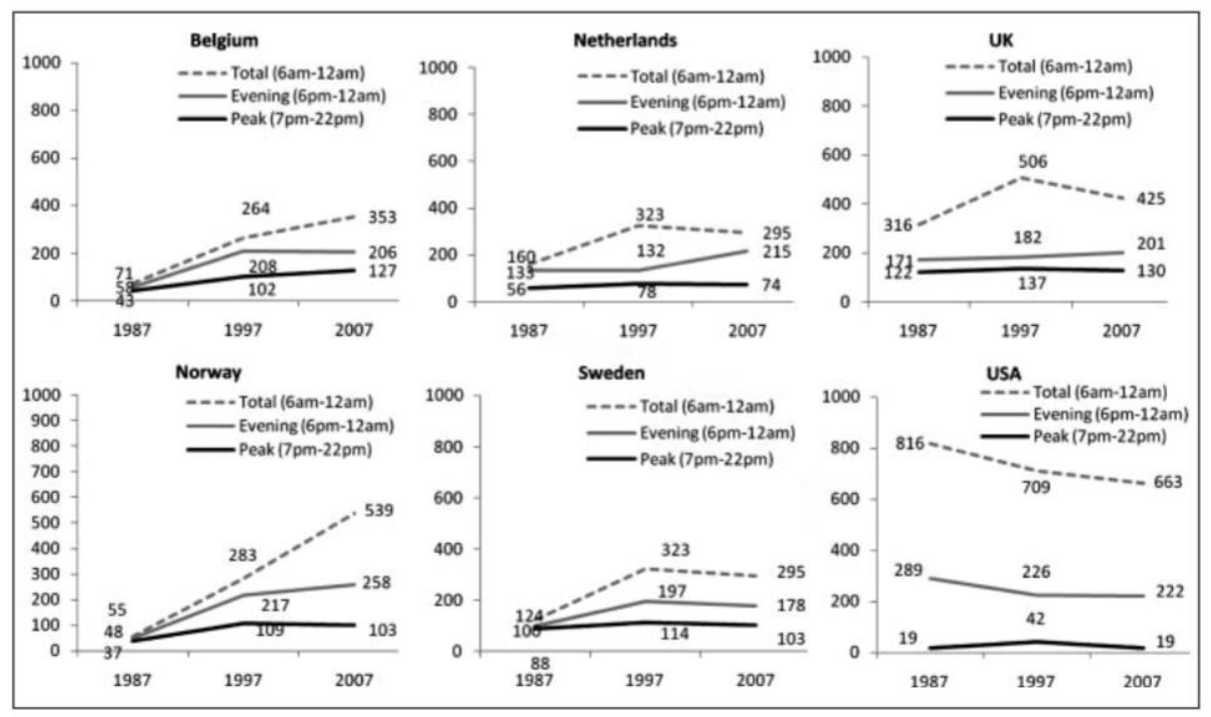

Figure 2: Supply of news and current affairs according to time of broadcast, 19872007: average minutes per day.

In a similar study with an expanded scope, Esser et al. (2012) examined news output in 13 countries over a period of 30 years from 1977 to 2007. They too found that public service media devoted more time during the evening to news and current affairs output than commercial broadcasters (the study did not include newspapers). In 2007, public service media across the 13 countries studied devoted a combined average of 7,454 minutes per week to newscasts (i.e. standard news bulletins), compared to 6,100 minutes on commercial channels. Public service media also broadcast more minutes of news-related programming, such as news magazines, news in brief, and news-related discussions. 
However, Esser et al. reported mixed findings with regards to news scheduling, and as consequence, did not straightforwardly link public service media with the development of national TV environments that offer the "most advantageous opportunity structure for informed citizenship". In Belgium, the Netherlands, Israel, Norway, Sweden and the United Kingdom, they found that generalist TV stations (whether public or commercial) together offered up to three opportunities for consuming news in the evening, but in Italy and Spain there is just one, because public and commercial stations broadcast news at the same time. In other words, although Scandinavian countries tend to perform well in this regard, "opportunity structures for capturing inadvertent audiences in some other European countries are not much more advantageous than on the broadcast networks in the United States" (Esser et al. 2012). This highlights that even within affluent European countries public service media vary significantly, and as studies adopt a broader geographical scope, consistent patterns become harder to identify. Public service media are not the same across the world, and we should not expect their impact to be the same.

Other recent research has focused on particular types of news. In a study of international news coverage in 11 countries across 5 continents, Aalberg et al. (2013) reported that public service media broadcast a larger proportion of hard news than commercial stations. Based on content analysis carried out in three non-consecutive weeks in 2010, they found that on average $56 \%$ of international coverage by public service media was hard news, compared to $41 \%$ of coverage from commercial broadcasters. However, in 4 of the 11 countries-Canada, Italy, South Korea, and Japan - total international news output (including hard and soft) from commercial broadcasters was larger. It is thus not a given that public service media generally provide more hard news of a given kind than private sector media-it depends on the specific public service media provider. Despite this, the authors concluded that "there is clear evidence that market-oriented broadcasting systems are less likely to supply their audiences with international hard news coverage" (Aalberg et al. 2013). Prior to these larger studies, (still relevant) research was carried out using a smaller pool of countries. In a study focusing on Denmark, Finland, the United States, and the United Kingdom, Curran et al. (2009) and Iyengar et al. (2010) found that TV markets characterised by a public service model (Denmark and Finland), as opposed to a mixed or commercial model (United Kingdom and United States respectively), devote more time to both hard news and international coverage. They compared the output of the two 'principal' television channels in each country (as well as a selection of daily newspapers) over four non-consecutive weeks in 2007, and reported, for example, that $71 \%$ of coverage from DR and TV2 in Denmark could be 
classed as hard news (compared to $63 \%$ in the United States), and that $27 \%$ reported international events (20\% in the United States) (Curran et al. 2009).

In comparing differences between public service media and commercial broadcasters they found that when averaged across the four countries, $78 \%$ of news coverage from public service media could be classed as hard news (as opposed to soft news), compared to $64 \%$ on commercial channels. This difference was particularly pronounced in Denmark (88\% and 54\%, with the state-owned broadcaster TV2 treated as a commercial channel because of its reliance on advertising revenues), but smaller in Finland and the United Kingdom. Taking public service media and commercial broadcasters together, the proportion of hard news coverage in Finland and Denmark was higher than in the United Kingdom and the United States. However, in terms of the proportion of international news coverage (as opposed to domestic), the authors found no difference between public service media and commercial broadcasters, and no significant differences between countries: $28 \%$ of news coverage from the Danish public service media was international, compared to $27 \%$ of the coverage from the commercial broadcaster (Iyengar et al. 2010).

A number of smaller individual studies have compared private sector and public service media coverage of a range of issues, including business/economic news (Lischka 2014) and international news (Ihlen et al. 2010), and found that public service media cover these issues more. The findings are hardly conclusive, however, as other studies contradict the results, or the results are not replicated across countries. Kolmer \& Semetko (2010) found little difference in the volume of foreign affairs reporting between German public and commercial channels, and d'Haenens et al. (2009) find that private and public media in the two Belgian communities, Flanders and Wallonia, simply have different priorities.

In some countries, certain stakeholders publish highly detailed and reliable information on both output and viewing, the full details of which are beyond the scope of this document (as they assess only output, not impact). In the United Kingdom, the most recent such report from communications regulator Ofcom (2015a) - based on data from a panel of 5,100 homes - revealed that in 2014 the BBC broadcast more news than any of the other main commercial stations: $39.9 \%$ of the main public service channel's (BBC One) output was news, compared to $12.2 \%$ on ITV, $4.0 \%$ on Channel 5 , and $3.9 \%$ on Channel $4 .^{3}$ This was also reflected in the

\footnotetext{
${ }^{3}$ The UK broadcast system regards the BBC, ITV, Channel 4 and Channel 5 all as public service broadcasters, but in this report for the sake of convenience we distinguish between the BBC as a publicly funded and owned PSB, and the others which are all commercially funded but with varying
} 
proportion of time viewers spend watching particular genres, with $23.4 \%$ of time spent viewing BBC One spent watching news, compared to $6.7 \%$ of ITV, $4.7 \%$ of Channel 4, and 3.4\% of Channel 5. During peak times (defined as 18:00 to 22:30), the same pattern holds, but the differences between public and commercial channels are far less pronounced. The report did not distinguish between hard and soft news output.

Similarly, research from Media Perspektiven (a journal published by the German public service media organisation ARD) by Krüger (2016) found that German public service media channels (ARD and ZDF) broadcast more news and information programmes than commercial channels (RTL, Sat.1, and ProSieben) between 2013 and 2015, and that within the main news shows on each, those on public service media devoted more coverage to hard news topics such as politics and economics. A study by the Austrian public service media organisation ORF in cooperation with the European Broadcasting Union (EBU) and a handful of other public service media organisations, carried out in the context of public value assessment, found a similar pattern in Switzerland based on content analysis of 2 weeks of output in 2013 (ORF 2016).

Cross-national data from stakeholders is currently very scarce, but basic information on certain topics is starting to emerge. For example, though this is something of a niche issue, a recent survey by the EBU (2016b) of arrangements for parliamentary broadcast services (broadcasting directly from parliament) in 40 European countries found that public service media have "a strong role in providing citizens with parliamentary coverage". More specifically, they observed that public service media have a role in broadcasting parliamentary coverage to citizens in 19 of the 30 countries that offer some kind of dedicated or non-dedicated service. The study does not examine what kind of audience these services draw.

\section{Limitations}

On balance, the available research on news provision points to the fact that public service media broadcast more hard news, and more news at peak viewing times, than commercial channels. But research in this area perhaps suffers from a lack of consistent measurement. Given that each study appears to measure slightly different things, and does so in a largely subjective way, many findings are either contradicted in other research, or have not been replicated. Furthermore, there is perhaps a tendency to gloss over data that shows little difference between

degrees of public service obligations. It should be noted that Channel 4 is state owned whereas ITV and Channel 5 are commercially owned. 
commercial and public service media output, and to prioritise results that highlight a gap. Academic research so far has been more interested in testing whether public service media provide hard news than whether, and under what conditions, public service media provide more hard news than particular kinds of private sector media. Finally, research in this area rarely compares the output of public service media with that of newspapers, which have in some countries been found to be the most important producers of national (Lund 2000, Lund et al. 2009, Pew 2010) and local news (Nielsen 2015).

\subsection{Public service media help increase knowledge of politics, current affairs, and international events}

A large number of studies have concluded that individual exposure to public service media news - or living in a media environment with significant public service provision - increases knowledge of a variety of hard news topics, including politics, current affairs, and international events (Curran et al. 2009, 2012; Iyengar et al. 2010; Aalberg et al. 2013). However, studies that have studied a broader range of public service media point out that this benefit is contingent on financing, independence, and audience share (Soroka et al. 2013). Again, not all public service media systems are the same, and not all forms of public service provision are equally impactful. Most studies have argued that public service media are particularly good at reducing knowledge gaps by serving those with low interest and motivation, (though a few studies dispute this; see Jenssen et al. 2012; Fraile \& Iyengar 2014). Furthermore, some doubt whether a causal relationship between public service media and increased knowledge can be adequately demonstrated through the use of cross-sectional surveys (Jenssen 2009). However, more recent studies have directly addressed this flaw by conducting panel-based research that allows differences in knowledge in the same individuals to be studied before and after exposure to particular news sources (Shehata et al. 2015). Several sources have found higher knowledge gains from morning newspaper reading, but not for tabloid newspapers or commercial television news (e.g. de Vreese and Boomgaarden 2006; Fraile and Iyengar 2014).

As part of the study mentioned in the previous subsection, Curran et al. (2009) and Iyengar et al. (2010) examined the impact of inhabiting a public service oriented media system on political knowledge in Denmark, Finland, the United States, and the United Kingdom. To do this they combined their content analysis with a survey of knowledge about different types of news. The results of their survey showed that overall knowledge of hard news was highest in Denmark and Finland, and knowledge of international news was higher in Denmark, Finland, and the United 
Kingdom than in the United States, showing that public service media not only publish hard news, but that this also makes a difference in terms of outcomes.

One reason for this is that knowledge gaps between advantaged and disadvantaged groups (such as those with low education, low income, and ethnic minorities) are particularly large in the United States, with the effect of lowering average knowledge scores (Curran et al. 2009). Results of multivariate analysis further showed that the typically lower knowledge scores in the United States were caused by the fact that those who are less interested in politics are less likely to benefit from news coverage due to reduced incidental exposure. However, in Scandinavia "it is possible for the less interested to overcome their motivational handicap because of the greater availability of news programming" (Iyengar et al. 2010), in part due to public service media that not only publish hard news, but also routinely reach wide audiences. (Whether the United States can be used as representative of what a market-dominated media environment would look like in a small high-income country is a different issue. We have not identified any studies comparing similarsize countries with different levels of public service intervention, like for example Denmark and New Zealand.)

In a detailed book-length study, Aalberg and Curran (2012) complemented their aforementioned six-country content analysis (United States, United Kingdom, Sweden, Finland, Belgium, the Netherlands) with a survey that probed individuallevel news consumption and public affairs knowledge. They broadly concluded that "public service television sustains a higher level of public affairs knowledge than market-based television" and that "this is borne out, not merely by the difference in the level of knowledge in the US and northern Europe, but also by differences within nations". In short, because public service media broadcast more hard news at peak times, citizens-particularly those who lack the interest and motivation to seek out this information-are left better informed, especially in countries where public service news reach wide and diverse audiences.

However, individual chapters within the Aalberg and Curran book offer a more complicated picture. There were clear differences between the United States and northern Europe in terms of levels of current affairs knowledge, likely due to the fact that public service media have a larger overall audience share and TV viewers are more likely to be public service media viewers in the European countries studied (Curran et al. 2012). But importantly, when the impact of individual exposure to public service media news and commercial broadcasters' news on political knowledge and political trust was measured within countries, the positive effects of public service media news consumption on both disappeared when level of 
education was introduced into the analysis as a control (Aarts et al. 2012). In other words, national-level differences in trust and knowledge may be better explained by factors other than exposure to public service media news, and a link between the two may be a result of self-selection (the idea that people with already high political knowledge/trust chose to consume news from public service media because it meets their needs). That being said, Jenssen et al. (2012) were able to find a modest positive association between the use of public service media news and knowledge of political parties and their policies.

In a later study, Aalberg et al. (2013) combined their content analysis of international hard news output in 11 countries with a survey probing levels of international news knowledge. At the national level, they found a positive linear association $(r=0.58)$ between the percentage of international coverage that can be classified as hard news (of which public service media broadcast more) and the average knowledge scores in each country. However, evidence of this association was based on a small number of observations $(n=11)$ and is heavily dependent on the data from Norway and Greece (see Figure 3).

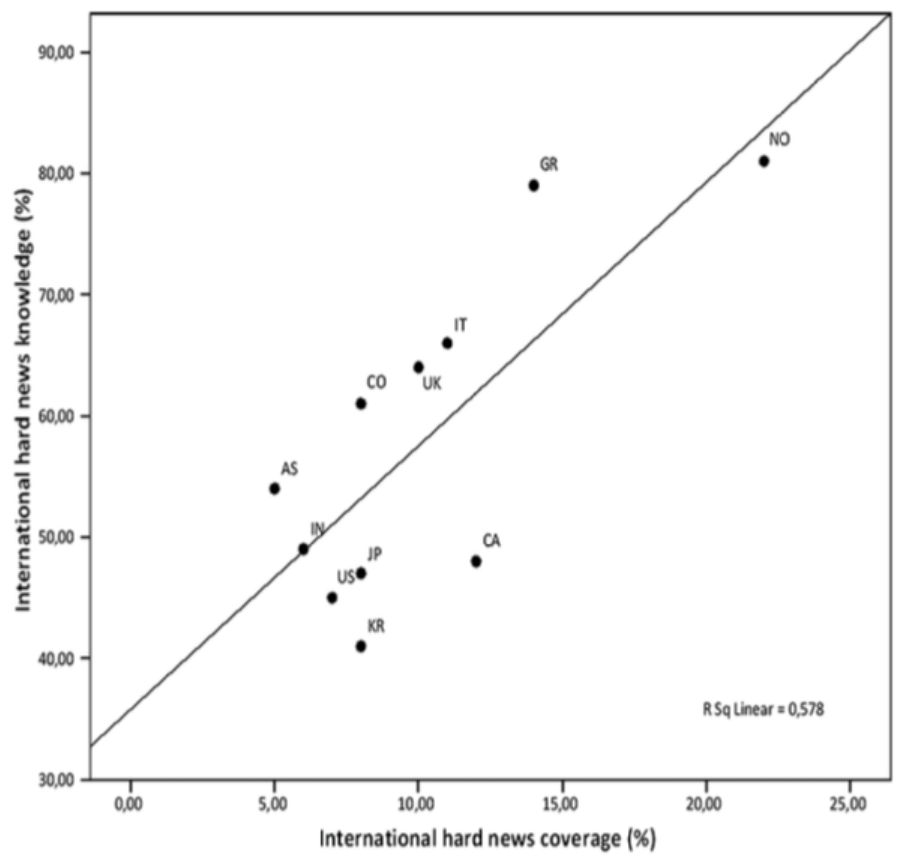

Figure 3: The relationship between supply and knowledge of international hard news (Aalberg et al. 2013).

Soroka et al. (2013) examined the impact of public service media news consumption on hard news knowledge in six countries (Canada, Italy, Japan, Norway, South Korea, and the United Kingdom). They used an online survey containing questions about past media consumption and political knowledge to show that "in Norway, and to lesser extent in Canada and Japan, exposure to news from the public channel 
has a stronger positive effect on overall knowledge than exposure to commercial television news". In these countries there were also smaller knowledge gains from watching commercial TV, but in the United Kingdom "those who watched BBC news scored higher than those who did not, but those who regularly consumed news from the leading commercial channel, ITV, scored lower". In examining the UK case, the authors went one step further and analysed the effect of exposure to the state-owned but commercially funded Channel 4, and found that-as they predicted-knowledge gains from exposure were lower than from the BBC but greater than from the commercial channel ITV.

In attempting to sidestep problems associated with self-selection, and to make more robust causal claims, the authors used 'propensity score analysis' to approximate randomness by creating two demographically similar groups within the data; one containing those that consumed news from a public service media organisation, and one containing those that did not.

In the final part of their analysis, Soroka et al. (2013) examined potential causes of national-level differences in knowledge gaps between audiences for public service media and commercial broadcasters (or in other words, plotting various factors against the ability of public service media to increase knowledge). They found that there is a modest positive association between both the level of public service media funding and the public service media audience share with the knowledge gap. However, they found a stronger relationship between the level of legal (de jure) independence that public service media enjoys and the knowledge gap (see Figure 4). So, again, not all public service media systems are the same, nor are all public service media providers. Effects are context dependent and conditional, in this case in a way that suggests significant positive political impact of public service media in the Nordic countries (represented in Figure 4 by Norway).
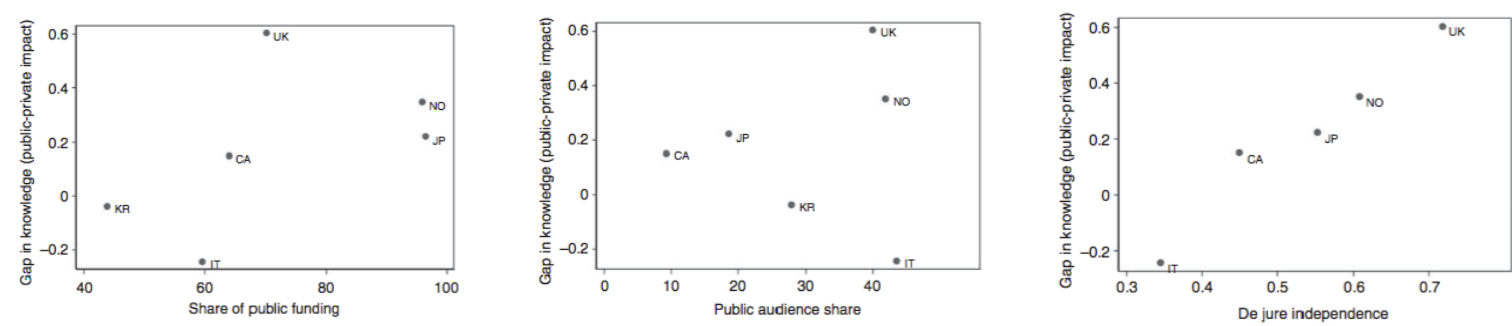

Figure 4: System measures and the knowledge gap (Soroka et al. 2013).

Fraile and Iyengar (2014) conducted secondary analysis of 2009 European Election Survey data from 27 European Union (EU) countries - which contains data on political knowledge and news consumption - to show that "exposure to newscasts from public broadcasters exerts significant positive effects on knowledge", but 
"exposure to news provided by commercial broadcasters has the opposite effect". The authors arrived at this conclusion using multilevel regression, but also used propensity score analysis (see above) in order to be more confident about the causal relationship implied by this claim. Fraile and Iyengar (2014) also showed - by using education as a measure of resource inequality, and political interest as a measure of motivation - that exposure to news from public service media, although it is responsible for overall increases, does not have the effect of levelling knowledge gaps. They did, however, find that broadsheet newspapers are effective in this regard. In other words, "broadsheet newspapers present relevant informative effects that reduce the knowledge gap between low resource and unmotivated citizens and their high resource and motivated counterparts" (Fraile and Iyengar 2014).

In contrast to some other earlier studies, Jenssen (2009) was not able to link increases in political knowledge to exposure to either public service media or commercial broadcasters. Using data from the 1997-2001 Norwegian Election Survey, Jenssen was able to use longitudinal (rather than cross-sectional) analysis to examine the effect of exposure to political coverage on NRK (public service) and TV2 (commercial) over time on knowledge of Norwegian politics. Though he was able to observe a significant bivariate association between viewing the debates on TV and political knowledge, this disappeared when controls based on education and prior knowledge were introduced. In other words, Jenssen was able to assess levels of political knowledge within the same group of people before and after exposure to political coverage, finding no discernible increases. On this basis, Jenssen questioned the causal relationship implied by studies on the same topic, arguing that associating public service media exposure and increased knowledge at a single point in time may simply highlight that those who happen to be more knowledgeable may be selfselecting sources of information on this basis. (The same could apply to the finding that newspaper reading is associated with higher levels of political knowledge.) In response, Shehata et al. (2015) used four-wave survey data collected during the 2010 Swedish national election to show that individuals experienced significant knowledge growth over time following exposure to the Swedish public service provider SVT. The survey measured exposure to different sources of news, as well as political knowledge through the use of 32 questions (8 per wave). At the most basic level, the authors found that public service media news use was strongly associated with political knowledge, estimating that "one additional day of public service television viewing increases knowledge by approximately one correct answer on the 0-32 learning scale". 
As this study made use of a panel, it was possible for the authors to observe individual-level differences in knowledge over time. In doing so, the authors found that "the average growth in knowledge is significantly stronger among citizens who regularly watch public service television channels". Shehata et al. were also able to confirm a hypothesis on 'inadvertent learning', the idea that knowledge can be acquired passively and independently of the influence of interest and motivation.

More specifically, their results showed that "irrespective of how politically interested citizens are, how much attention they pay to political news, and how much they discuss politics with friends and family, watching public service television makes a difference. Those who rely on these channels still learn more". They also found that although public service media news consumption increases knowledge for all levels of interest in politics, those with low interest gained the most (see Figure 5). More precisely, "going from a strong entertainment-oriented exposure to a strong public service oriented exposure (i.e., moving from 0 to 10) is related to an increase in between-wave learning by 4.04 correct responses among the least interested, but only .95 among those with a strong interest in politics".

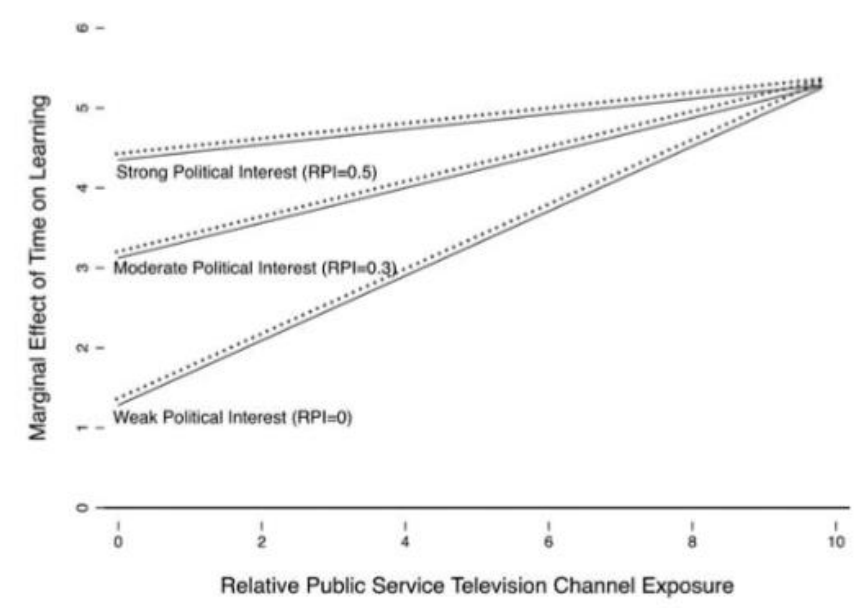

Figure 5: The marginal effect of time on knowledge growth (Shehata et al. 2015).

Strömbäck (2016) later added extra dimensions to this study. First, he showed thatin the Swedish case - the positive association between public service media news and knowledge does not change within periods of varying political 'intensity', with the effect being the same leading up to a national election, a European election, and with no election imminent. Secondly, in comparing two different public service media news programmes (Aktuellt and Rapport) he also found that "knowledge effects are stronger for one public service TV news show than for the other", reminding us that "it is not ownership [public service versus private sector] per se that is decisive. The format and the content also matter". As several studies have found, some newspapers and some commercial broadcasters can have as positive an 
impact on political outcomes as public service media: it all depends on the combination of (a) producing hard news and (b) in turn reaching a wide and diverse audience with it, increasing political information levels, and decreasing information inequality.

As with much investigations into the effect of public service TV news output on knowledge. empirical research on the impact of public service media, online output has rarely been studied in terms of its effect on knowledge. In a non-representative survey of 571 pupils from $8^{\text {th }}$ to $13^{\text {th }}$ grade in Germany, Schmitt $(2014)$ examined the role public service media play online for the political knowledge of young people. Findings show that young people who rely on professional journalistic sources online, especially public service media, have better political knowledge than others who consume more entertaining news on private media websites or social media. However, their research design did not test for causality. Indeed, pupils who were performing better at school were more likely to use public service media websites and had a better political knowledge, suggesting that self-selection is a factor. In this sense, though valuable, this study suffers from the same weakness as some of the earlier

\section{Limitations}

On balance, the available research suggests a positive relationship between public service news use and political information levels. As is the case across almost all research into public service media, the most detailed and careful studies tend to focus on prominent, well-funded broadcasters in the Nordic countries and Western Europe, at the expense of public service media across Europe and the rest of the world. We know that these providers can operate quite differently, not least because some of them depend heavily on advertising and are less politically independent and trusted, so we might also expect there to be different patterns of knowledge acquisition. Although concerns around causation are starting to be addressed, at present this has only been achieved for single-country studies (these are, however, often from the Nordic countries, similar to Denmark.) Approaches based on panel surveys may prove difficult to replicate across multiple countries. Even with panel surveys, there may be little reason to expect significant changes in certain types of knowledge over relatively short periods of time, even though there may be considerable gains in the long term. This is all compounded by the fact that more recent research has highlighted that different programmes and audience reach (rather than public or private ownership in itself) is what appears to have an impact on knowledge. Finally, while the results concerning commercial broadcast news vary, newspaper reading is more consistently linked to knowledge gains than 
broadcast news, underlining that many different sources can help citizens learn more about society.

\subsection{Public service media may increase propensity to vote}

There exists some but comparatively weak evidence to suggest that exposure to public service media, or public service oriented media systems more generally, increases political participation, measured at the individual level as propensity to vote, or at the aggregate level as turnout in elections (de Vreese \& Boomgaarden 2006; Baek 2009). Only a handful of recent studies have addressed this issue, with their conclusions tempered either by a lack of specificity or a lack of generalizability.

In a wide-ranging study, de Vreese and Boomgaarden (2006) investigated the impact of different forms of media consumption on political knowledge and intention to vote in Denmark and the Netherlands, with a particular focus on EU politics ahead of a 2002 European Council meeting. Based on a combination of content analysis and a two-wave panel survey carried out in 2002, they found that exposure to public service media news in each country increased political knowledge and stated likelihood of voting.

The results of the content analysis, based on news output from the period between each wave of the survey, showed that "public broadcasting had more news about the EU (32\%) than commercial news (24\%) in Denmark and in the Netherlands (6 and $4 \%$, respectively)", but that overall levels of political coverage were similar between public service media and commercial broadcasters (see Figure 6). In both countries, public service media featured more 'EU actors' than commercial stations (see Figure 7). In the Netherlands, public service media were less likely to employ a conflict-driven narrative, with the opposite true in Denmark (see Figure 8).

However, in all cases, the differences between public service media and commercial coverage were quite small.

Following on from this, by examining differences between the results from the first and second waves of the survey, they were able to show "after controlling for socialdemographics and the respondents' initial level of knowledge (measured at wave I), that exposure to public broadcasting news affected the knowledge level in the second wave of our panel in both Denmark and the Netherlands". Exposure to commercial news also increased knowledge in Denmark, but not in the Netherlands. 


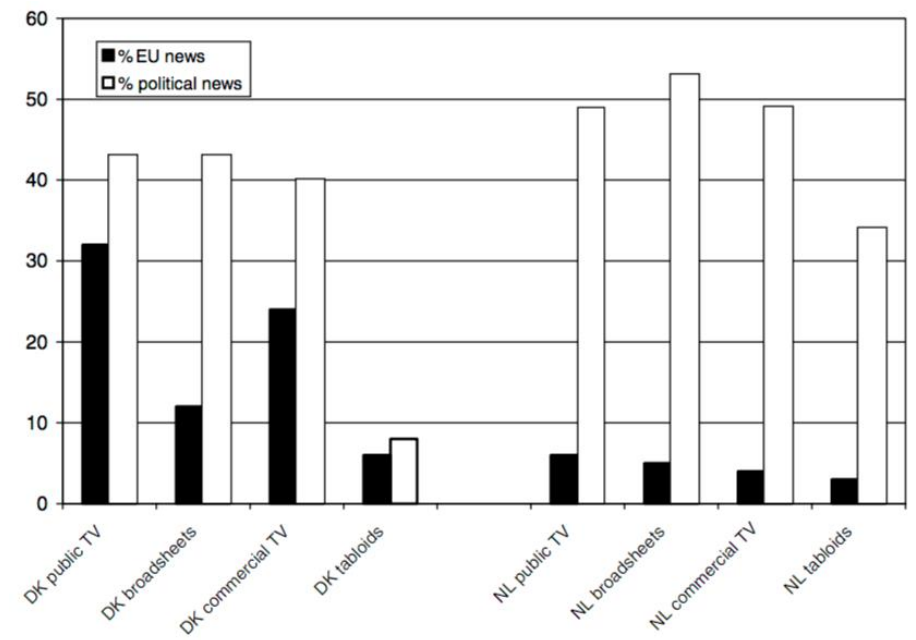

Figure 6: Share of EU news and other political news on public vs commercial television news and in broadsheet vs tabloid newspapers (de Vreese \& Boomgaarden 2006).

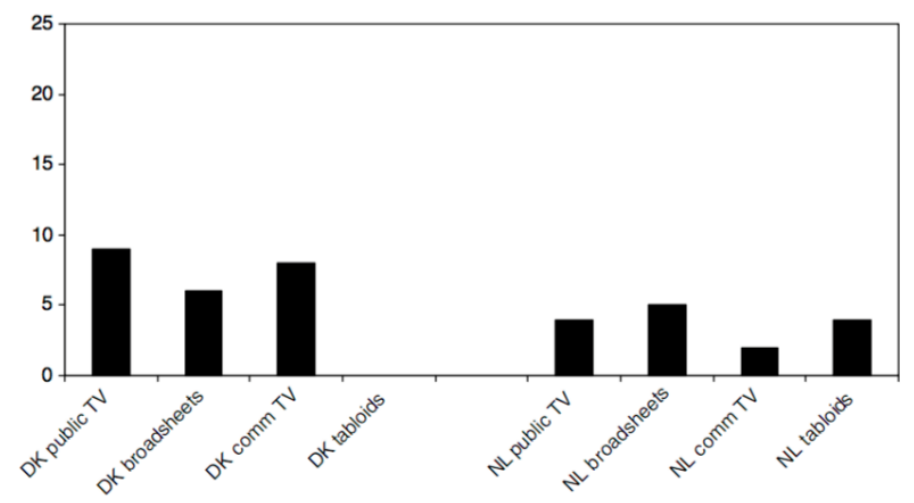

Figure 7: Share of EU actors on public vs. commercial television news and in broadsheet vs tabloid newspapers (de Vreese \& Boomgaarden 2006).

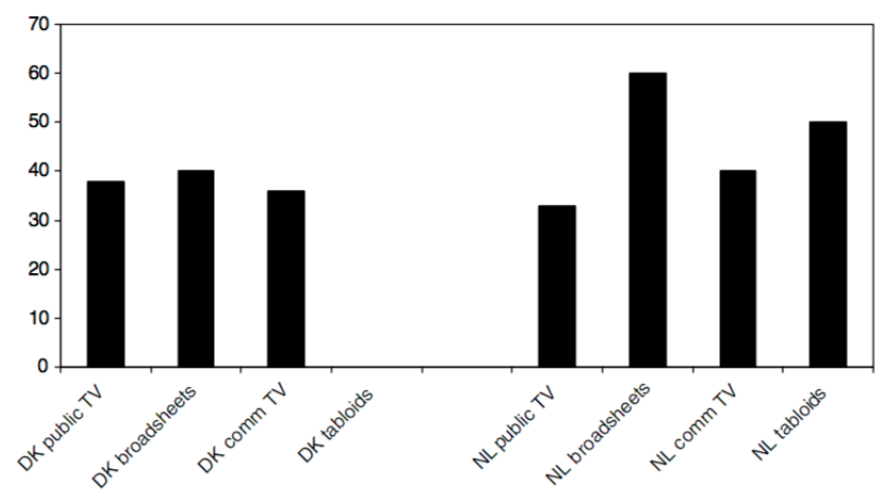

Figure 8: Share of conflict-driven news on public vs commercial television news and in broadsheet vs tabloid newspapers (de Vreese \& Boomgaarden 2006). 
In terms of voting, de Vreese and Boomgaarden (2006) found that exposure to any type of news media increased stated likelihood of voting in both Denmark and the Netherlands (with the exception of tabloid newspaper reading in Denmark), but with very slightly more positive effects from exposure to public service media news. However, it should be acknowledged that voting propensity is an imperfect indicator of actual voting habits.

The effect of public service media on political participation has also been examined at the national level. Baek (2009) compiled national data from 74 countries from a number of different sources and showed that public or state media systems, or mixed public/private systems (as opposed to private), have a positive effect on voter turnout rates. More specifically, "the average turnout rate of private systems is significantly lower than that of state/public and mixed systems by $13 \%(p=0.01)$ and $11 \%(p=0.02)$, respectively. However, voter turnout differences between state/public and mixed systems are not significant $(p=0.5)$ ". Furthermore, a $1 \%$ increase in public service media TV audience share corresponds to an average increase of $0.15 \%$ voter turnout, with an even stronger effect in advanced democracies.

Stakeholder research in this area is limited, but a recent study published by the EBU (2016a) reached a similar conclusion using a simpler and much less robust form of analysis. Based on national-level data from 35 European countries, they found a straightforward positive correlation $(r=0.53)$ between public service media market share and voter turnout. However, they acknowledged that "the strength of the correlation between the two variables is moderate, demonstrating that there are many other factors at play that influence citizens' democratic participation". The same study also observed that high public service media market share is associated with a low public demand for right-wing extremism and a high degree of control over corruption. However, the study did not establish a causal relationship between public service media market share and any of these other measures and did not control for other factors.

\section{Limitations}

On balance, the available research suggests that there may be a slight positive relationship between public service media and political participation, but research in this area is limited. There is an obvious gap in the literature regarding the impact that public service media might have on actual voting among individuals, rather than intention to vote. At the national level, it is likely that voter turnout levels are also influenced by factors separate from the media. It should also be remembered that political participation can take many different forms, both formal and informal, 
and we are not aware of any research that has examined the potential impact of public service media in this regard. 
Political impact— table of sources

\begin{tabular}{|c|c|c|}
\hline Study & Method & Relevant Conclusions \\
\hline $\begin{array}{l}\text { Aalberg \& Curran } \\
\text { (2012) }\end{array}$ & $\begin{array}{l}\text { Quantitative content analysis of } \\
\text { TV schedules from } 6 \text { countries } \\
\text { between } 1987 \text { and } 2007 \text {. Online } \\
\text { survey in } 6 \text { countries on news } \\
\text { consumption, public affairs } \\
\text { knowledge, and other relevant } \\
\text { indicators. }\end{array}$ & $\begin{array}{l}\text { Public service media broadcast more } \\
\text { news and current affairs programmes } \\
\text { than commercial stations, and are more } \\
\text { likely to broadcast them at peak viewing } \\
\text { times. As a result, public affairs } \\
\text { knowledge is higher in countries with } \\
\text { public service oriented systems, and } \\
\text { among those within countries that } \\
\text { consume news from public service } \\
\text { media. }\end{array}$ \\
\hline Aalberg et al. $(2010)^{*}$ & $\begin{array}{l}\text { Quantitative content analysis of } \\
\text { TV schedules from } 6 \text { countries } \\
\text { between } 1987 \text { and } 2007 \text {. }\end{array}$ & $\begin{array}{l}\text { Public service media broadcast more } \\
\text { news and current affairs programmes at } \\
\text { peak times than commercial stations. } \\
\text { Therefore, public service media do more } \\
\text { to inform the public. }\end{array}$ \\
\hline Aalberg et al. (2013)* & $\begin{array}{l}\text { Quantitative content analysis of } \\
\text { TV news output in } 11 \text { countries in } \\
\text { 2010. Online survey and face-to- } \\
\text { face interviews consisting of } 6 \\
\text { multiple choice questions on } \\
\text { foreign affairs topics. }\end{array}$ & $\begin{array}{l}\text { Proportion of international news } \\
\text { coverage from public service media that } \\
\text { can be classed as hard news is higher } \\
\text { than that from commercial broadcasters. } \\
\text { There is a positive linear association at } \\
\text { the national level between proportion of } \\
\text { international coverage that is hard news } \\
\text { and average knowledge of international } \\
\text { news. }\end{array}$ \\
\hline Aarts et al. (2012) & See Aalberg \& Curran (2012). & $\begin{array}{l}\text { Public service media news consumption } \\
\text { within each country is associated with } \\
\text { increased levels of political knowledge } \\
\text { and political trust. However, level of } \\
\text { education has a larger effect. }\end{array}$ \\
\hline Baek (2009)* & $\begin{array}{l}\text { Comparative quantitative } \\
\text { analysis of national-level data on } \\
74 \text { countries. }\end{array}$ & $\begin{array}{l}\text { Countries with public/state or mixed } \\
\text { public/private media systems have a } \\
\text { higher voter turnout than purely private } \\
\text { systems. In the case of public/state } \\
\text { systems, the positive effect is only }\end{array}$ \\
\hline
\end{tabular}




\begin{tabular}{|c|c|c|}
\hline & & $\begin{array}{l}\text { present if broadcasters permit paid } \\
\text { political advertising. }\end{array}$ \\
\hline Curran et al. (2009)* & $\begin{array}{l}\text { Quantitative content analysis of } \\
\text { TV news output (and } \\
\text { newspapers) in } 4 \text { countries in } \\
\text { 2007. Online survey consisting of } \\
28 \text { multiple choice questions on } \\
\text { hard and soft news knowledge. }\end{array}$ & $\begin{array}{l}\text { Both public and commercial } \\
\text { broadcasters within public service } \\
\text { oriented systems broadcast a higher } \\
\text { proportion of hard news and } \\
\text { international affairs than broadcasters } \\
\text { within commercial or mixed systems. }\end{array}$ \\
\hline Curran et al. (2012) & See Aalberg \& Curran (2012). & $\begin{array}{l}\text { Knowledge of current affairs is higher in } \\
\text { countries with public service oriented } \\
\text { media systems (as opposed to } \\
\text { commercial systems). }\end{array}$ \\
\hline 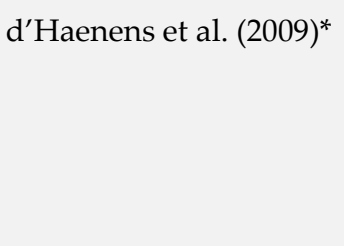 & $\begin{array}{l}\text { Secondary analysis of data on } \\
\text { output from a variety of sources. }\end{array}$ & $\begin{array}{l}\text { Public service media and commercial } \\
\text { channels in Belgium have different } \\
\text { priorities, which in turn results in } \\
\text { different output. }\end{array}$ \\
\hline $\begin{array}{l}\text { de Vreese \& } \\
\text { Boomgaarden }(2006)^{*}\end{array}$ & $\begin{array}{l}\text { Two-wave panel survey and } \\
\text { content analysis conducted in } \\
2002 \text { in Denmark and the } \\
\text { Netherlands. Survey contained } \\
\text { questions on media exposure, } \\
\text { political knowledge, and } \\
\text { intention to vote. }\end{array}$ & $\begin{array}{l}\text { In both countries, public service media } \\
\text { tended to broadcast more news about } \\
\text { EU politics than commercial } \\
\text { broadcasters, leading to increases in } \\
\text { knowledge of EU politics and increases } \\
\text { in stated likelihood of voting. However, } \\
\text { differences in effects of public service } \\
\text { media and commercial broadcasters } \\
\text { were usually very small. }\end{array}$ \\
\hline EBU (2016a) & $\begin{array}{l}\text { Comparative quantitative } \\
\text { analysis of national-level data on } \\
\text { around } 40 \text { countries (depending } \\
\text { on available data from other } \\
\text { sources). }\end{array}$ & $\begin{array}{l}\text { Public service media market share is } \\
\text { positively associated with voter turnout } \\
\text { and control over corruption, but } \\
\text { negatively associate with demand for } \\
\text { right-wing extremism. }\end{array}$ \\
\hline EBU (2016b) & $\begin{array}{l}\text { National-level survey of } 40 \\
\text { European countries. }\end{array}$ & $\begin{array}{l}\text { Public service media play a role in } 19 \text { out } \\
\text { of the } 30 \text { countries surveyed that offer a } \\
\text { parliamentary broadcast service. }\end{array}$ \\
\hline
\end{tabular}




\begin{tabular}{|c|c|c|}
\hline Esser et al. $(2012)^{*}$ & $\begin{array}{l}\text { Quantitative content analysis of } \\
\text { TV schedules from } 13 \text { countries } \\
\text { between } 1977 \text { and } 2007 \text {. }\end{array}$ & $\begin{array}{l}\text { Public service media broadcast more } \\
\text { news and current affairs programmes in } \\
\text { total, but different approaches to } \\
\text { scheduling mean that public service } \\
\text { media do not always create } \\
\text { environments that offer the best } \\
\text { information opportunities. }\end{array}$ \\
\hline $\begin{array}{l}\text { Fraile \& Iyengar } \\
(2014)^{*}\end{array}$ & $\begin{array}{l}\text { Secondary analysis of European } \\
\text { Elections Survey data from } 27 \mathrm{EU} \\
\text { countries, itself based on } \\
\text { telephone interviewing. Survey } \\
\text { included questions on political } \\
\text { knowledge and news } \\
\text { consumption. }\end{array}$ & $\begin{array}{l}\text { Exposure to public service media news is } \\
\text { effective in increasing political } \\
\text { knowledge. However, unlike broadsheet } \\
\text { newspapers, public service media do not } \\
\text { significantly reduce knowledge gaps } \\
\text { between those with varying levels of } \\
\text { education and political interest. }\end{array}$ \\
\hline Ihlen et al. (2010) & $\begin{array}{l}\text { Content analysis in Norway } \\
\text { during } 4 \text { month period in } 2007 .\end{array}$ & $\begin{array}{l}\text { Norwegian public service media spend } \\
\text { more time covering international news } \\
\text { than commercial channels. }\end{array}$ \\
\hline Iyengar et al. (2009)* & $\begin{array}{l}\text { Quantitative content analysis of } \\
\text { TV news output (and } \\
\text { newspapers) in } 2 \text { countries in } \\
2004-2005 \text {. }\end{array}$ & $\begin{array}{l}\text { Swiss media contained more references } \\
\text { to specific predefined hard news topics } \\
\text { than the US media over a } 1 \text { year period. }\end{array}$ \\
\hline Iyengar et al. (2010)* & $\begin{array}{l}\text { Quantitative content analysis of } \\
\text { TV news output (and } \\
\text { newspapers) in } 4 \text { countries in } \\
2007 \text {. Online survey consisting of } \\
28 \text { multiple choice questions on } \\
\text { hard and soft news knowledge. }\end{array}$ & $\begin{array}{l}\text { Public service media broadcast a larger } \\
\text { proportion of hard news coverage than } \\
\text { commercial stations. Those who inhabit } \\
\text { public service oriented systems are more } \\
\text { knowledgeable about hard news topics } \\
\text { and international affairs. Due to } \\
\text { scheduling of news output, those in } \\
\text { Scandinavia who are less interested in } \\
\text { politics are still nonetheless left } \\
\text { relatively knowledgeable. }\end{array}$ \\
\hline Jenssen( 2009) & $\begin{array}{l}\text { Secondary analysis of 1997-2001 } \\
\text { longitudinal Norwegian Election } \\
\text { Survey data. Survey included } \\
\text { questions on political knowledge } \\
\text { and news consumption. }\end{array}$ & $\begin{array}{l}\text { Exposure to public service media (or } \\
\text { commercial) political coverage does not } \\
\text { significantly increase political } \\
\text { knowledge if controls reflecting prior }\end{array}$ \\
\hline
\end{tabular}




\begin{tabular}{|c|c|c|}
\hline & & $\begin{array}{l}\text { knowledge and education are } \\
\text { introduced. }\end{array}$ \\
\hline Jenssen et al. (2012) & See Aalberg \& Curran (2012). & $\begin{array}{l}\text { Public service media consumption has a } \\
\text { small but positive effect on knowledge } \\
\text { of political parties and their respective } \\
\text { policies. }\end{array}$ \\
\hline $\begin{array}{l}\text { Kolmer \& Semetko } \\
(2010)^{*}\end{array}$ & $\begin{array}{l}\text { Content analysis of German TV } \\
\text { output between } 2001 \text { and } 2007 \text {. }\end{array}$ & $\begin{array}{l}\text { German public service media do not } \\
\text { broadcast more foreign affairs reporting } \\
\text { than commercial channels. }\end{array}$ \\
\hline Krüger $(2016)^{*}$ & $\begin{array}{l}\text { Content analysis of TV output in } \\
\text { Germany between } 2013 \text { and } 2015 \text {. }\end{array}$ & $\begin{array}{l}\text { German public service media broadcast } \\
\text { more news and information } \\
\text { programmes than commercial channels } \\
\text { between } 2013 \text { and } 2015 \text {, and that within } \\
\text { the main news shows on each, those on } \\
\text { public service media devoted more } \\
\text { coverage to hard news topics. }\end{array}$ \\
\hline Lischka $(2014)^{*}$ & $\begin{array}{l}\text { Content analysis of German news } \\
\text { sources between } 2002 \text { and } 2010 .\end{array}$ & $\begin{array}{l}\text { Public service media cover business and } \\
\text { economic news more than commercial } \\
\text { broadcasters in Germany. }\end{array}$ \\
\hline Ofcom (2015a) & $\begin{array}{l}\text { Quantitative analysis of data } \\
\text { from a panel of } 5,100 \text { homes in } \\
\text { the United Kingdom. }\end{array}$ & $\begin{array}{l}\text { The main public service channel (BBC } \\
\text { One) broadcasted more news in } 2014 \\
\text { than commercial channels (both at peak } \\
\text { times and overall). As a result, BBC One } \\
\text { viewers spent a larger proportion of time } \\
\text { watching news. }\end{array}$ \\
\hline ORF (2016) & $\begin{array}{l}\text { Content analysis of } 2 \text { weeks of } \\
\text { output in } 2013 .\end{array}$ & $\begin{array}{l}\text { Public service media in Switzerland } \\
\text { devoted more coverage to hard news } \\
\text { topics than commercial channels. }\end{array}$ \\
\hline Schmitt (2014) & $\begin{array}{l}\text { Survey of school-age children in } \\
\text { Germany on news consumption } \\
\text { and political knowledge. }\end{array}$ & $\begin{array}{l}\text { Online public service media news } \\
\text { consumption is associated with higher } \\
\text { levels of political knowledge, whereas } \\
\text { use of commercial and social media is } \\
\text { associated with lower levels of political } \\
\text { knowledge. }\end{array}$ \\
\hline
\end{tabular}




\begin{tabular}{|c|c|c|}
\hline \multirow[t]{8}{*}{ Shehata et al. $(2015)^{*}$} & Four-wave panel survey in & The Swedish public service broadcaster \\
\hline & Sweden, conducted in 2010 and & SVT increased individual political \\
\hline & containing questions on news & knowledge over time in the period \\
\hline & exposure and political & leading up to the 2010 national election. \\
\hline & knowledge. & SVT fostered 'inadvertent learning', with \\
\hline & & knowledge gains highest among those \\
\hline & & least motivated and least interested in \\
\hline & & politics. \\
\hline \multirow[t]{8}{*}{ Soroka et al. $(2013)^{*}$} & Online survey in 6 countries & Exposure to public service media news \\
\hline & consisting of questions about & was more effective in increasing \\
\hline & media consumption and 10-16 & knowledge than commercial \\
\hline & questions on political knowledge. & broadcasters in 4 of the 6 countries. The \\
\hline & & gap between knowledge increases from \\
\hline & & public service media and commercial \\
\hline & & broadcasters were linked to funding, \\
\hline & & audience share, and independence. \\
\hline \multirow[t]{8}{*}{ (Strömbäck 2016)* $^{*}$} & Four-wave panel survey in & Consuming news from the Swedish \\
\hline & Sweden, conducted in 2010 and & public service broadcaster SVT is \\
\hline & containing questions on news & associated with increased individual \\
\hline & exposure and political & political knowledge. This effect on \\
\hline & knowledge. & knowledge did not change in varying \\
\hline & & periods of political intensity. Different \\
\hline & & public service media news programmes \\
\hline & & had different effects on knowledge. \\
\hline
\end{tabular}

Note: * indicates a peer-reviewed study. 


\section{Social impact}

Research on the social impact of public service media is less well developed than research on political impact. The EBU identifies a range of possible indicators of public service media's social impact, including investment in cultural programming (national drama, stage art, music), diversity and inclusivity (coverage of minority arts, less popular sports, on-screen diversity in terms of journalists, anchors, hosts, and actors), heritage (maintenance of archives, collaboration with museums and other cultural institutions), and coverage of science, history, and technology (through documentaries, etc.) (EBU 2015).

Most public service media organisations are committed to (and required to provide) such social services, and their volume of output and audience for such services is frequently tracked by regulators or others (Ofcom in the United Kingdom, for example). If seen as having intrinsic value, the diversity and character of public service media output (and the degree to which it differs from what private sector media provide) can be seen as a form of impact in itself, even if no clear causal link can be established to external effects.

Research going beyond measuring output, use, and in some cases user satisfaction, is scarce. The main focus of the research that exists on the social impact of public service media has been (a) their impact on overall levels of trust (in institutions and individuals) and (b) inclusivity (whether public service media serve as levellers in terms of reducing inequalities in political knowledge, participation, etc.). In line with a broader research interest in how media can foster social cohesion/social integration and increase social capital by strengthening community ties (e.g. Janowitz 1957; Stamm 1985; Putnam 2000; Lowrey et al. 2008; Richards 2012) we had expected to find studies examining (c) the impact of public service media in this area, but have found none.

The studies reviewed have linked the presence of public service media to an overall higher degree of trust in both institutions and individuals and suggested that public service media are able to promote inclusivity and social cohesion by helping people develop a more realistic understanding of the society they live in, and well as suggesting that public service media, in countries where these are widely trusted by the population, can help increase trust in the media overall.

The research reviewed in this area is generally based on relatively solid research designs. Findings have typically been neither replicated nor contradicted, as there are few studies in this area. No studies deploy stronger designs such as panel surveys or experiments. Thus we have some evidence of social impact, but not enough research to establish an evidence-based consensus. 
Key findings from the reviewed research are summarised in Box 2. Below, we discuss main points from a selection of the most important studies in greater detail. The table at the end of the chapter summarise the methods and conclusions of the studies discussed.

\section{Box 2: Social impact-key findings from existing research}

Findings from a limited amount of existing research

- Available data on output shows that public service media produce different kinds of content from commercial broadcasters, and that satisfaction levels tend to be higher for public service media.

- Aggregate levels of social trust tend to be higher in countries with public service oriented media systems.

- Exposure to public service media (as opposed to commercial broadcast news) is associated with more realistic perceptions of society, particularly concerning crime and immigration.

- Public service oriented media systems may foster trust in television as a whole.

The number of studies described in this chapter is much smaller than in Chapter 2. We have identified 11 relevant academic studies and 5 stakeholder studies. One reason for this is that most of the empirical academic work on the impact of public service media has focused on political consequences. Furthermore, most relevant stakeholder research is focused on output within individual countries. Some are currently embarking on large cross-national projects that are likely to eventually produce relevant results, such as the EBU's 'Public Service Media Contribution to Society Project', but so far they have produced only a handful of relevant publications (e.g. EBU 2016a, 2016b). In contrast to work focused on the political impact of public service media, no clear causal chain is implied by the findings. However, each is likely to be a result of the patterns of scheduling and content described earlier.

\subsection{Some public service media achieve higher levels of audience satisfaction}

Taken together, a fragmented body of research partly shows that, although it is difficult to discern consistent patterns in terms of output, measures of satisfaction are usually higher for public broadcasters. The data underpinning this finding usually comes from stakeholders, such as regulatory bodies or public service media 
themselves. Academic studies that have attempted to measure diversity within public service media output have reported mixed findings.

In the United Kingdom, the communications regulator Ofcom releases detailed data annually on output that is potentially relevant to societal impact (e.g. Ofcom 2015a). The picture is complex due to the large number of possible output measures, but to take 'arts and classical music' and 'religion and ethics' as two examples, we see that BBC Two devoted more airtime to these in 2014 than commercial channels (see Figure 9). However, we can also see that both ITV and Channel 5 devoted more airtime to drama and soaps, which may also benefit society, depending on the goal and the precise content.

\begin{tabular}{|c|c|c|c|c|c|c|c|c|c|c|c|c|c|c|c|}
\hline & \multicolumn{3}{|c|}{ Bac One } & \multicolumn{3}{|c|}{ Bac Two } & \multicolumn{3}{|c|}{ mVhrV Breakfast } & \multicolumn{3}{|c|}{ Channel 4} & \multicolumn{3}{|c|}{ Channel 5} \\
\hline & 2009 & 2013 & 2014 & 2009 & 2013 & 2014 & 2000 & 2013 & 2014 & 2009 & 2013 & 2014 & 2009 & 2013 & 2014 \\
\hline News & 2,719 & 3,591 & 3.620 & 1.207 & 898 & 852 & 1,585 & 1,196 & 1,181 & 535 & 485 & 480 & 740 & 848 & 853 \\
\hline $\begin{array}{c}\text { Arts } \\
8 \text { Classical Musid }\end{array}$ & 86 & 40 & 34 & 243 & 253 & 234 & 31 & 24 & 28 & 67 & 96 & 64 & 52 & 43 & 39 \\
\hline Religion \& Emics & 105 & 88 & 87 & 42 & 64 & 57 & 21 & 2 & 2 & 49 & 22 & 11 & 12 & 52 & 42 \\
\hline Education & 27 & 22 & 20 & 362 & 348 & 329 & 0 & 0 & 0 & 410 & 13 & 5 & 252 & 0 & 0 \\
\hline Factual & 2.209 & 2,168 & 2,142 & 1,914 & 3,433 & 3,433 & 2,736 & 2,817 & 2.871 & 2.292 & 2,588 & 3.024 & 1,356 & 1,661 & 2,113 \\
\hline Drama \& Soaps & 1,002 & 591 & 660 & 515 & 302 & 287 & 1,444 & 929 & 742 & 950 & 563 & 538 & 2,033 & 1,766 & 1,312 \\
\hline $\begin{array}{c}\text { Entertainment \& } \\
\text { Comedy }\end{array}$ & 634 & 902 & 782 & 596 & 688 & 569 & 1,016 & 1,462 & 1,611 & 2,330 & 2.801 & 2,756 & 745 & 648 & 989 \\
\hline Feature Films & 603 & 496 & 331 & 642 & 782 & 760 & 870 & 519 & 521 & 1,142 & 1,209 & 1,018 & 1,073 & 927 & 923 \\
\hline Sports & 575 & 635 & 811 & 918 & 942 & 1,277 & 338 & 347 & 384 & 654 & 710 & 814 & 981 & 139 & 95 \\
\hline Children's & 497 & 5 & 2 & 1,740 & 12 & 21 & 419 & 316 & 308 & 331 & 283 & 50 & 1,258 & 1,560 & 1,501 \\
\hline Total & 8,457 & 8,537 & 8,469 & 8,179 & 7,722 & 7,819 & 8,460 & 7,632 & 7,648 & 8,760 & 8,760 & 8,760 & 8,501 & 7,644 & 7,867 \\
\hline
\end{tabular}

Figure 9: Genre mix on the main five UK channels - all hours of output, all day (Ofcom 2015a).

In Germany, a similar picture has been reported, with commercial channels on average providing more potentially impactful fictional and non-fiction content, in part because they devote less time to news (Krüger 2016). However, in the absence of detailed content analysis carried out with the specific aim of identifying output that may have an effect on important issues within society, the available data do not allow us to say with certainty that public service media deliver output that is likely to have societal impact, and how exactly they differ from different private sector competitors.

On the basis of data from the European Audiovisual Observatory, Hanretty (2012) found that across Europe the amount of hours devoted to news, factual, and arts and culture programming increases in line with the share of total public funding allocated to public service media. However, he was also careful to point out that 
"countries that have public service broadcasters that score highly on their public service remit also have commercial broadcasters that do well on the same metric". He also found that public service media tend to broadcast more domestic content than commercial stations (which may help to foster a stronger national identity).

Most public service media publish their own yearly measures of how well they are performing based on audience surveys. These figures tend to suggest that public service media are generally viewed positively. For example, the BBC's 2014/15 Annual Report (BBC 2015) stated that their television output has an 'appreciation index' of 80.9 (80.2 for radio and 76.0 for online). In Germany, the available data suggests that trust levels for news on public service media are higher than for commercial channels (Zubayr \& Geese 2013). However, a study commissioned by the BBC and discussed in greater detail in Chapter 4 showed a strong positive correlation between audience perceptions of the main public television channels versus the main private channels (BBC 2013). The scores for public service channels varied, but the public service media channels had the best evaluations by the audience in the United Kingdom and the worst in Spain and Italy. For the commercial channels and audience perception, the range was from United Kingdom, Australia, United States, and the Netherlands at the top to Spain, Italy, Germany, and Japan at the bottom.

In the United Kingdom at least, stakeholders provide more useful data on user satisfaction - particularly with respect to how well broadcasters are performing in the eyes of those within certain groups. Ofcom (2015a) has consistently reported high levels of satisfaction with BBC output from different groups within the United Kingdom, with figures in some cases slightly higher than for the main commercial broadcaster (ITV). With respect to local news coverage within specific regions, in their most recent survey, around three-quarters of respondents in Wales (77\%), Scotland $(74 \%)$, and Northern Ireland $(87 \%)$ said of BBC One that "its regional news programmes provide a wide range of good quality news about my area", with similar figures for ITV (Wales 74\%, Scotland 75\%, Northern Ireland 88\%). Considering output more generally, $63 \%$ of BBC One viewers said that it "shows different kinds of cultures within the United Kingdom" and 64\% said that it "shows different parts of the United Kingdom". These figures are higher than equivalent figures for ITV (52\% and 55\%), Channel 4 (53\% and 46\%) and Channel 5 (38\% and 35\%), suggesting that the $\mathrm{BBC}$ is seen as performing better in this regard.

In the United Kingdom, Ofcom (2015b) has also recently published research specifically focused on measuring attitudes towards the representation of diversity in terms of regional programming, age, gender, ethnic minorities, religion, LGBT, 
and disabilities. Unfortunately, the data does not distinguish between the BBC and commercial channels, so comparing the two is not possible. In terms of most of the above dimensions, in most cases a majority of viewers across all channels said they felt that the representation of each is 'about right'. However, $48 \%$ said that they felt there were too few people with disabilities on TV and more generally, those within the groups in question did not always agree that they were sufficiently represented. ${ }^{4}$

Some academic studies have attempted to measure diversity within public service media output. In a study of 11 countries, Tiffen et al. (2014) analysed differences between the sources quoted in the news. The study is part of a larger comparative project entitled 'Media System, Political Context and Informed Citizenship: A Comparative Study'. The project relies, apart from a survey of citizen knowledge and attitudes, on a content analysis of 9 countries discussed here. This quantitative content analysis of major news media (broadcast, print and online) was conducted in most countries during five consecutive weekdays in three non-sequential weeks in 2010. For each country an analysis of two (evening peak-hour) television news programmes was conducted, one for a public service channel (in Colombia and the United States there is no public service TV broadcaster of major consequence, so two commercial channels were analysed), and one for the leading commercial channel. In addition, two newspapers - a quality newspaper and, where applicable, a largecirculation popular newspaper - were analysed (in several countries it was decided to study two quality newspapers). The leading news website was also included in each country. The study compared the prevalence of single-sourced stories involving conflict in commercial as opposed to public service television. They found that public service media vary considerably in this respect in the different countries: "The United Kingdom (and Australia and India) had the strongest contrast, with their PSBs leading the commercials in source diversity; Canada and Japan (and Greece) had negligible differences, while in Italy the PSBs were far more single source dependent than the commercial sector" (Tiffen et al., 2014, p. 388). Furthermore, they looked at the balance in the news stories. They found that in the United Kingdom and Australia commercial TV and tabloid newspapers are more likely than public service TV and quality newspapers to give only one side of a conflict. This distribution also applies to Indian TV. For most other countries there is no difference, but in Italy public service television and quality newspapers in a conflictual story are more likely to cover only one side when compared with commercial television and tabloid newspapers.

\footnotetext{
${ }^{4}$ The state-owned but commercially funded UK broadcaster Channel 4 provides its own research, including a survey where respondents put it ahead of the other main British broadcasters, including the BBC, in terms of showing the viewpoints of different minority groups (Channel 4 2015, p. 34).
} 
Micro-level studies include content analysis on the representation of different social groups, for example in Dutch television (Koeman, Peeters, \& d'Haenens, 2007), or migration diversity in Irish television (Rogers, O’Boyle, Preston, \& Fehr, 2014). The study by Koeman et al. (2007) is a quantitative analysis of the representation of different groups, with a particular focus on gender, age, and ethnicity in prime-time programmes in Dutch public service and commercial channels. The study shows only marginal differences between public and commercial channels. The gender ratio on Dutch TV for both does not correspond with the composition of the Dutch population. Furthermore, there is, for both, no correspondence with age. Children and adolescents as well as seniors are under-represented, although the public channels represent them more often than the commercial channels. Concerning ethnicity, there is no comparative data for Dutch society as a whole. The findings of the study show, however, that about $80 \%$ of individual shown on Dutch television are white, the remaining $20 \%$ consisting of non-whites or being 'different/unknown'. The public service broadcaster represents more people of Mediterranean and Asian descent, whereas commercial channels more often represent people with a darker skin (the authors point out that this may be explained by a larger number of American films and series).

Rogers et al. (2014) analyse how public service and commercial broadcast media in Ireland reflect migration-related diversity and migrant integration. The core material drawn upon in the article is the findings of an exploratory, pilot-level European research project ('Media for Diversity and Migrant Integration', MEDIVA). The empirical study compares the MEDIVA findings regarding the roles and representations of third-country nationals in the context of RTE (the Irish public service broadcaster) and TV3 (a commercial channel). The authors examine the performance of these broadcasters in this respect in terms of programme production processes, recruitment practices, media training, and content output. The findings show relatively little difference in the approach of public service and commercial broadcasters on migrant diversity. The authors conclude: "While MEDIVA does not make it possible to claim that PSB far outperforms its commercial counterparts in the domain of migrant diversity, the findings still consistently illustrate public service broadcasters to be more willing to acknowledge and accommodate migrant audiences and issues in terms of programme production and content output. Equally, the employment and recruitment practices of PSBs demonstrate greater awareness and accommodation of migrant communities. As such, it is possible to argue that when it comes to migrant diversity, PSB still retains a public service function, and a role that is not matched by private media" (Rogers et al., 2014, p. 412f.). 
The studies reviewed here thus do not provide a basis for saying that public service media are systematically more diverse than private sector media in terms of how they cover society.

\section{Limitations}

As most of the data on output was not collected for the purposes of measuring social impact, the categories used are in most cases too broad to be of use. Where it is available, survey data on satisfaction - particularly in terms of how well certain groups are represented-is useful, but often the most specific studies have not sought to compare public service media and commercial channels. In general, data is only available for a very small number of countries, and as most comes from national stakeholders, comparisons with different types of broadcaster or different countries are not a priority for those carrying out the research.

\subsection{Popular public service media are associated with social trust}

Schmitt-Beck and Wolsing (2010) used multilevel analysis of data from the 2002 and 2004 waves of the European Social Survey (ESS), supplemented with TV consumption data, on 21 European countries to show that countries with public service media that have a high TV audience share have higher levels of social trust, defined broadly as both trust between individuals and trust between individuals and institutions.

In response to earlier studies that generally found negligible associations between individual TV exposure and trust, Schmitt-Beck and Wolsing instead examined how aggregate levels of TV consumption within countries are associated with social trust. In their own words, they found that "aggregate patterns of TV use are much more important for individuals' social trust than their personal viewing habits thus indicating the presence of strong indirect effects. Moreover, TV per se does not appear to be detrimental to people's confidence in one another. While the overall viewing time is negatively related to social trust, the share of time spent watching public broadcasting programs seems to nourish individuals' trust in their fellow citizens". Schmitt-Beck and Wolsing's findings on social trust are broadly in line with findings from earlier research by Pippa Norris (2000), which found a much broader positive relation between news media use and confidence in a range of social and political institutions. Using survey data from the European Election Studies and Eurobarometer, Norris (2000) generally found what she called a "virtuous circle", a positive or neutral relation between news media use and confidence in various institutions. She saw this as a refutation of the thesis that news media drive a "spiral of cynicism" undermining public trust. Importantly, her analysis does not distinguish between private sector news media use and public service media news media use. 


\section{Limitations}

Aside from the fact that more studies are required to validate this finding, the above studies are based on cross-sectional survey data and thus the question of causation remains. While there seems to be an association between strong popular public service media and social trust, some research has found the same broad correlation with news use more generally, and no studies have systematically analysed impact over time, controlling for other possible factors influencing social trust.

\subsection{Public service news consumption leads to more realistic perceptions of society}

A small number of studies have argued that public service media help individuals develop more realistic perceptions of society, particularly concerning crime and immigration (Pfeiffer et al. 2005; Strabac et al. 2012). Here, the argument is that public service media are less likely to broadcast fictional content, and are less prone to sensationalism in their news coverage. However, none of the studies described here have properly dealt with the concerns around causation and self-selection.

Pfeiffer et al. (2005) used a survey to show that in Germany those who watch more public service media output (as opposed to commercial) are less likely to incorrectly believe that crime levels are in Germany are rising, as those that do so are less exposed to unrealistic fictional depictions of society.

As part of the previously mentioned study by Aalberg and Curran (2012), Strabac et al. (2012) used the six-country survey to show that in Norway, Sweden and the Netherlands, public service media use was negatively associated with antiimmigration sentiment, and in all countries other than the United States consuming news from commercial broadcasters was positively associated. Similarly, Jacobs et al. (2014) used structural equation modelling to show that in the Flanders region of Belgium, whereas overall TV consumption was associated with increased antiimmigration sentiment and increased fear of crime, those with a preference for public service media reported lower levels of anti-immigration sentiment and as a result, reported a lower fear of crime.

\section{Limitations}

Concerning the impact of public service media on fear of crime and immigration, most studies are yet to address the ever-present issues around causation and selfselection. More broadly, of course, perceptions of many other aspects of society may be influenced by the media. It is also unclear whether public service media have a positive impact in this area, or whether any supposed benefits are simply by virtue of them not being commercially funded. 


\subsection{Public service media may help foster trust in TV as a whole}

A handful of studies have argued that, within Europe, differences in how public service media are regulated and/or funded impacts upon trust in TV and the quality of its output (Connolly \& Hargreaves Heap 2007; Connolly et al. 2015). No direct comparisons are made between public service media and commercial broadcasters, but rather between different approaches to public broadcasting. Furthermore, it is (not unreasonably) assumed that the quality of TV has an impact on wider society.

A national-level study by Connolly and Hargreaves Heap (2007) of 26 European countries showed that overall levels of trust in TV are "significantly lower when [public service media] are regulated by government ministry as opposed to selfregulation [...] but there is no significant difference between levels of trust under an independent regulatory authority and self-regulation". However, "levels of trust do not seem to be affected by the form in which [public service media] obligations are set out or by whether there is a separate regulator for commercial television". The authors claim that trust in TV is important because "of the special influence that television plays in the political system but also because there is evidence that trust in institutions directly contributes to individuals' subjective well-being". However, they did not themselves empirically link trust in TV to any specific societal benefits.

In terms of stakeholder research, a national-level study by the EBU (2016a) found that public service media market share is linked to trust in broadcasting. More specifically, they observed that public service media radio market share was strongly and positively correlated $(r=0.64)$ with trust in radio (as measured by Eurobarometer), and public service media TV market share is moderately correlated with trust in TV $(r=$ 0.46). However, as with other parts of this research discussed in Chapter 2, as these findings were based on simple correlation tests, it is unclear what other factors might influence trust, and whether a robust causal relationship exists.

\section{Limitations}

Although it appears that public service media may be beneficial to TV as a whole, at the moment it is not completely clear (from these studies, at least) whether this is a mechanism for delivering benefits to wider society. 
Social impact-table of sources

\begin{tabular}{|c|c|c|}
\hline Study & Method & Relevant conclusions \\
\hline BBC (2013) & $\begin{array}{l}\text { Cross-sectional analysis of TV } \\
\text { markets in } 14 \text { countries. }\end{array}$ & $\begin{array}{l}\text { Statistically significant positive } \\
\text { correlation between commercial market } \\
\text { outcomes and public service media } \\
\text { strength in most areas and most } \\
\text { countries. }\end{array}$ \\
\hline BBC (2015) & $\begin{array}{l}\text { Survey of the UK public service } \\
\text { media audience carried out in } \\
2014 .\end{array}$ & $\begin{array}{l}\text { The } \mathrm{BBC} \text { has (seemingly) high } \\
\text { satisfaction ratings for their } \mathrm{TV} \text {, radio, } \\
\text { and online services. }\end{array}$ \\
\hline $\begin{array}{l}\text { Connolly \& } \\
\text { Hargreaves Heap } \\
(2007)^{*}\end{array}$ & $\begin{array}{l}\text { Secondary quantitative analysis } \\
\text { of data from a variety of sources } \\
\text { pertaining to } 26 \text { European } \\
\text { countries. }\end{array}$ & $\begin{array}{l}\text { Overall trust in TV is higher in countries } \\
\text { where public service media are either } \\
\text { self-regulated or regulated by an } \\
\text { independent authority (as opposed to } \\
\text { government regulated). }\end{array}$ \\
\hline EBU (2016a) & $\begin{array}{l}\text { Comparative quantitative } \\
\text { analysis of national-level data on } \\
\text { around } 40 \text { countries (depending } \\
\text { on available data from other } \\
\text { sources). }\end{array}$ & $\begin{array}{l}\text { Across Europe, public service media } \\
\text { market share is positively associated } \\
\text { with both trust in radio and trust in TV. }\end{array}$ \\
\hline Hanretty (2012) & $\begin{array}{l}\text { Secondary quantitative analysis } \\
\text { of data from a variety of sources } \\
\text { pertaining to broadcasters in } \\
\text { Europe. }\end{array}$ & $\begin{array}{l}\text { Across Europe, the amount of time } \\
\text { devoted by public service media to } \\
\text { news, factual, and arts and culture } \\
\text { programming is positively associated } \\
\text { with the share of total public funding } \\
\text { allocated to public service media. Public } \\
\text { service media output more domestic } \\
\text { content that commercial channels. }\end{array}$ \\
\hline Jacobs et al. (2014) & $\begin{array}{l}\text { Structural equation modelling } \\
\text { based on secondary analysis of } \\
\text { data from the Social Cohesion } \\
\text { Indicators in Flanders (SCIF) } \\
\text { survey, carried out in 2009, which } \\
\text { also contained questions on } \\
\text { media use. }\end{array}$ & $\begin{array}{l}\text { Preference for public service media } \\
\text { associated with lower levels of anti- } \\
\text { immigration sentiment and lower fear of } \\
\text { crime, whereas overall TV consumption } \\
\text { was associated with increased anti- } \\
\text { immigration sentiment and increased } \\
\text { fear of crime. }\end{array}$ \\
\hline
\end{tabular}




\begin{tabular}{|c|c|c|}
\hline Koemann et al. $(2007)^{*}$ & $\begin{array}{l}\text { Content analysis of Dutch TV } \\
\text { carried out in } 2005 \text {. }\end{array}$ & $\begin{array}{l}\text { Marginal differences between public and } \\
\text { commercial channels in terms of the } \\
\text { representation of different groups within } \\
\text { society. }\end{array}$ \\
\hline Krüger (2016) & $\begin{array}{l}\text { Content analysis of TV output in } \\
\text { Germany between } 2013 \text { and } 2015 .\end{array}$ & $\begin{array}{l}\text { German public service media devoted } \\
\text { less time to fictional and non-fictional } \\
\text { (other than news) content between } 2013 \\
\text { and } 2015 \text { than commercial channels. }\end{array}$ \\
\hline Ofcom (2015a) & $\begin{array}{l}\text { Quantitative analysis of UK TV } \\
\text { output in } 2014 .\end{array}$ & $\begin{array}{l}\text { UK public service media channels } \\
\text { devote more airtime to some types of } \\
\text { programming that might benefit society, } \\
\text { but commercial stations broadcast more } \\
\text { of others. UK public service media } \\
\text { channels are seen to do a better job of } \\
\text { representing minority groups than } \\
\text { commercial channels. }\end{array}$ \\
\hline Ofcom (2015b) & $\begin{array}{l}\text { Survey of UK TV audience } \\
\text { carried out in } 2014 .\end{array}$ & $\begin{array}{l}\text { UK TV receives high approval ratings } \\
\text { for their representation of most minority } \\
\text { groups. However, those within these } \\
\text { groups expressed lower approval rates } \\
\text { than the general population. }\end{array}$ \\
\hline Pfeiffer et al. $(2005)^{*}$ & $\begin{array}{l}\text { Quantitative content analysis of } \\
\text { TV schedules in Germany } \\
\text { between } 1985 \text { and } 2003 \text {. Survey of } \\
\text { media use and crime perceptions } \\
\text { carried out in } 2004 \text {. }\end{array}$ & $\begin{array}{l}\text { TV viewing as a whole is associated with } \\
\text { the incorrect belief that crime in } \\
\text { Germany is rising. This is as a result of } \\
\text { the increase in fictional depiction of } \\
\text { crime. As such, those who use public } \\
\text { service media are less likely to hold this } \\
\text { incorrect belief. }\end{array}$ \\
\hline Rogers et al. $(2014)^{*}$ & $\begin{array}{l}\text { Multi-method study, including } \\
\text { content analysis of public service } \\
\text { and commercial broadcast media } \\
\text { in Ireland. }\end{array}$ & $\begin{array}{l}\text { Shows only marginal differences } \\
\text { between public and commercial } \\
\text { channels in terms of their representation } \\
\text { of migrants and migration. }\end{array}$ \\
\hline $\begin{array}{l}\text { Schmitt-Beck \& } \\
\text { Wolsing }(2010)^{*}\end{array}$ & $\begin{array}{l}\text { Secondary quantitative analysis } \\
\text { of data on } 21 \text { European countries } \\
\text { drawn from the } 2002 \text { and } 2004\end{array}$ & $\begin{array}{l}\text { Countries where public service media } \\
\text { have a large audience share have higher } \\
\text { aggregate levels of social trust, } \\
\text { regardless of individual exposure to TV. }\end{array}$ \\
\hline
\end{tabular}




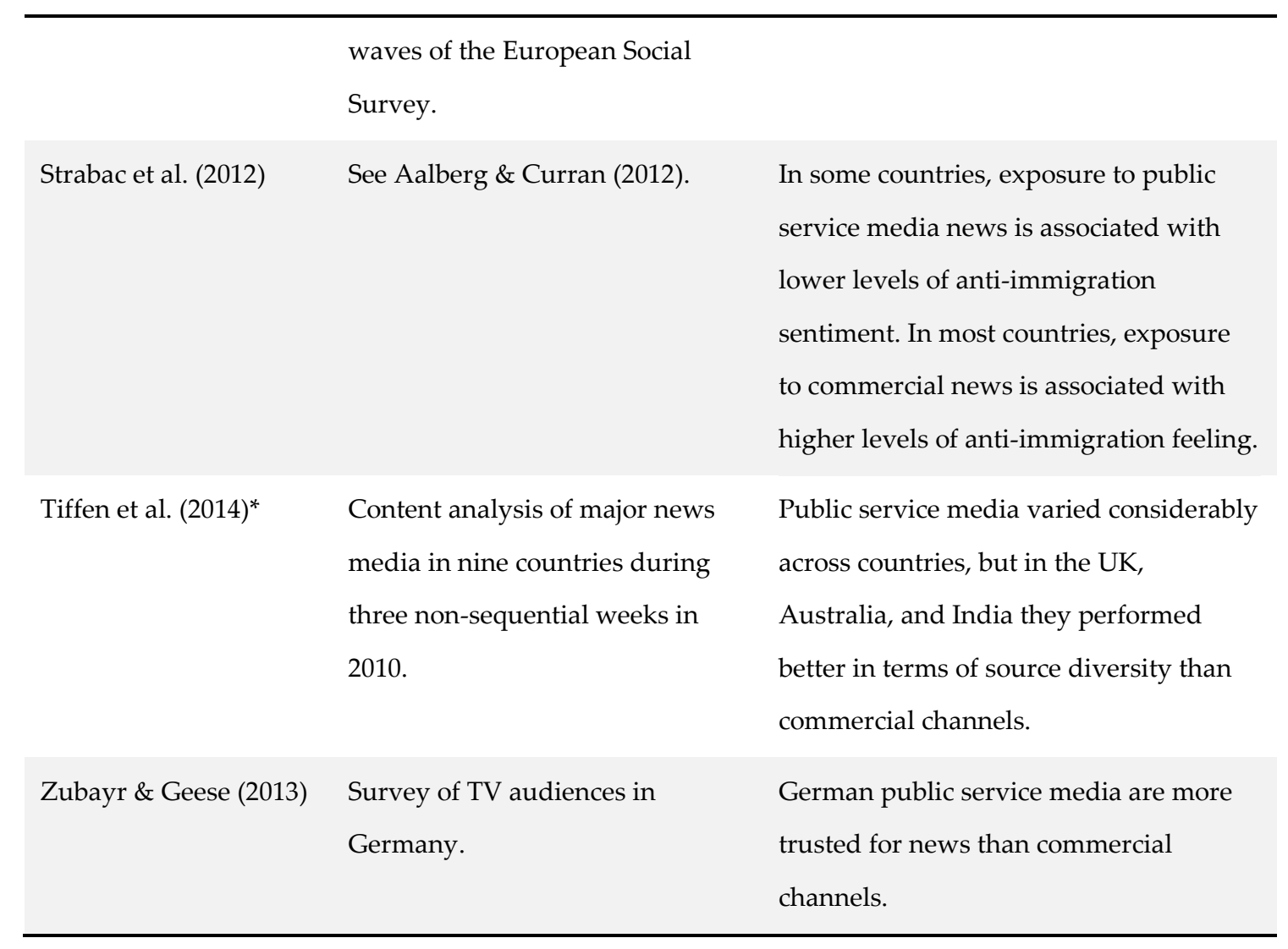

Note: * indicates a peer-reviewed study. 


\section{Market impact}

Given the importance of the issue and the intensity of the debates surrounding it, there is surprisingly little published, evidence-based research on the market impact of public service media. There is very little academic research in this area. We have identified only two recent and relevant academic studies. As Professor Patrick Barwise, one of the few academics who have published work in this area, wrote to us when we were conducting our review, "there seems to be very little (i.e. virtually no) academic research on the market impact of PSM/PSB. That's part of a wider issue, which is that, unfortunately, there isn't all that much academic work on media economics more generally." There is some published stakeholder research, funded either by governments and media regulators or by public service media or private sector media. We discuss seven such studies.

Broadly speaking, market impact research is concerned with whether public service media interventions are more likely to lead to a crowding out of private media, have no impact on private media, or have a net positive effect on private media through market conditioning/crowding in (where the pressure to compete induces a 'race to the top' that leads to better results for everyone). ${ }^{5}$ Specifically, researchers have considered the impact of public service media for (a) private sector media revenues, or (b) overall investments in content. Beyond this, market impact research has also been involved in the conduct of public value tests (PVTs) in a range of European countries.

Our main focus here is on the question of what impact public service media has on private sector media. There are very few evidence-based studies in this area. Some studies use theoretical modelling and counterfactual reasoning to assess the likely impact. Others use correlational designs to compare markets with different levels of public service media funding to assess the association between public service media funding and private sector media revenues. One study combined various forms of audience data to assess what the character and relative strength of public service provision means specifically for private sector news providers.

\footnotetext{
${ }^{5}$ Crowding out refers to the hypothesis that investment in public service content has a negative commercial impact by preventing new entrants from establishing themselves, encouraging market exit, and/or significantly lessening overall quality and investment by private sector media. Crowding in refers to the alternative hypothesis (sometimes called 'market conditioning') that public service content encourages rivals who compete for the same audience to spend more on content than they otherwise might, and that this 'race to the top' increases quality, draws in larger audiences, and grows the overall media sector for mutual benefit. As we will show, the empirical evidence for the two hypotheses is limited, mixed, and differs from country to country.
} 
Most of the evidence-based studies find little or no impact of public service media on private sector media. The research is, however, either limited in terms of data and methods, or primarily concerned specifically with the broadcast market. We therefore agree with the Swedish Media Commission (2016), which cautions against assuming that offline results will necessarily be replicated online, and underlines that more, more robust, and more up-to-date, research is necessary to form an evidence-based consensus.

Key findings from the reviewed research are summarised in Box 3. Below, we discuss main points from a selection of the most important studies in greater detail. The table at the end of the chapter summarises the methods and conclusions of the studies discussed.

\section{Box 3: Market impact-key findings from existing research}

Findings from a limited number of stakeholder studies

- Most studies find little or no impact of public service media on private sector media.

- The studies reviewed find limited impact of public service media on private media investment, and a net positive impact on investment in original content.

- A large majority of PVTs conducted across Europe have approved the public service provision put forth for evaluation. 7\% of 70 tests across 14 countries have resulted in rejection.

\subsection{Public service media impact on private sector media}

We have identified six evidence-based studies of public service media impact on private sector media. Five are from the United Kingdom (and three of these deal exclusively with the United Kingdom), one is from Norway, and one compared 14 high-income democracies across the world. In addition, we discuss one alternative framework for assessing possible market impact outlined in a piece of research commissioned by a trade group representing private media in Germany. None of these studies are peer reviewed, though one of them is by a pair of independent academics and not directly supported by any stakeholders. The five others are stakeholder research, three commissioned by public service media, two by governments. We have not identified any large-scale empirical assessment of the market impact of public service media commissioned by private sector media. 'Public and Private Broadcasters Across the World - The Race to the Top' (BBC 2013) was commissioned by the BBC and conducted by Dr Jonathan Simon from the 
consultancy company Inflection Point. It examines the relationship between the strength of private sector media and public service media in a comparative perspective. Using a range of different data sets, including date from Screen Digest, Ofcom, and the European Audiovisual Observatory, the study explores how commercial market outcomes (a composite measure of revenues per capita, investment per capita in original programmes, and schedule diversity) were related to public service media strength (a composite of public funding per capita, investment per capita in original programmes, and schedule diversity). Specifically concerning the impact of public service media on commercial revenues per capita, the study finds a positive correlation between public and commercial funding per capita. This is what the author calls a 'race to the top', arguing that the relationship between public service media and private sector media is not one of crowding out (of which no evidence is found), but of market conditioning, where public service media and private sector media compete for audiences, but not for revenues, and where the competition for audience forces everyone to raise their standards, drawing more people in and benefiting private sector media commercially. (This is a theoretical argument suggesting that correlation may in fact indicate causation. It is of course also possible that there is no causal link at all.) In most of the countries covered, there was a positive relationship between strong public service media and strong private sector media, not the negative relationship that the crowding-out hypothesis would lead one to expect. The positive relationship is most pronounced in Australia, the Nordic countries, and the United Kingdom (but considerably less so in Germany). Among the 14 countries examined, only the United States, with its very large domestic market, considerable export potential, and economies of scale, emerges as a strong outlier since it has the lowest level of public funding but the largest level of commercial revenues in the sample. For the other assessment criteria see the following sections 4.2 and 4.3 on the impact on content investments and diversity of supply. The study is widely cited and interesting, especially for the consistent results found across a range of countries. But its central limitation is that it presents a cross-sectional analysis of relationships at one particular point in time, rather than observations of change over time. It is thus helpful for identifying associations, but an actual study of impact would involve examining markets over time, especially in terms of whether decreases or increases in public service media funding were associated with significant changes in private sector media revenues. We have not been able to identify any studies conducting this kind of analysis in a comparative perspective.

An independent study by two media business experts, Patrick Barwise and Robert Picard (2014), ‘What if there were no BBC television?' starts from an empirical 
baseline, the UK television market in 2012, and then presents a counterfactual analysis of what it would look like without the BBC. This study focuses on the consequences for commercial television broadcasters as well as the British public as media users. The study compares the UK television market in 2012 with projections of what the market might have been like if there were no BBC television and no licence fee. The authors define the net impact of the BBC as the difference between the baseline and the different counterfactual scenarios. In contrast to the BBC (2013) study, Barwise and Picard assume throughout their analysis that the BBC crowds out some content investments by commercial broadcasters rather than producing net gains all around. As they put it, the crowding-out argument is a theoretical hypothesis rather than an established fact. They write "although this argument has been widely made, none of its proponents has to our knowledge provided any empirical evidence to support it" (Barwise and Picard 2014, p. 10). Because they base their modelling on the crowding-out hypothesis, rather than the market conditioning argument presented by Jonathan Simon in the BBC (2013) study, they call their analysis "rather conservative", and proceed from their baseline and the crowdingout hypothesis to outline what they consider to be, from the private sector media industry's point of view, one "very optimistic" and one "very pessimistic" scenario. They consider the midpoint between the two scenarios their "base case" and the most likely projection of what the UK television market would look like without the $\mathrm{BBC}$. Their scenarios give the likely changes in television subscription revenues (if there were no $\mathrm{BBC}$ ) as between zero and $+50 \%$, in television advertising as between $-15 \%$ and $+25 \%$, and the changes in other commercial revenues as between zero and $+30 \%$. In their base case, then, total television industry revenues would decline by $9 \%$ from $£ 12.3$ billion to $£ 11.2$ billion if there were no $B B C$, with combined commercial revenues growing by about $18 \%$ from $£ 9.5$ billion to $£ 11.2$ billion. The net impact for the television industry overall would be negative, but for commercial broadcasters it would be positive. (For the projected consequences for media users, in terms of investment in original content, see section 4.2.) This analysis has the advantage over BBC (2013) that it aims to capture the dynamic effects of public service media, rather than simply identifying associations in a single snapshot. Its limitation is its counterfactual nature and the wide range of assumptions that have to be made to conduct such a counterfactual analysis. The authors have aimed for realistic assumptions, but every one of them could have been a little different, leading to a different outcome.

PwC (2015) presents a similar study, based on counterfactual modelling using a computable general equilibrium model of the UK economy to assess impact across not only the media sector, but also the UK economy more broadly. The study was 
commissioned by the BBC as part of the charter review debate. As the study notes, "the work performed by PwC was performed in accordance with instructions provided by our client, the BBC, and was performed exclusively for their benefit and use. The document may therefore not include all matters relevant to the reader." The study examines two scenarios: (1) a nominal increase in licence fee revenue of $15 \%$ by 2021/22, implemented gradually and (2) a nominal decrease in licence fee revenue of $25 \%$ by $2021 / 22$, implemented gradually. One the basis of a series of assumptions, the study estimates how the BBC, other TV providers, and households will adjust their spending levels in response. The study does not go beyond TV. In Scenario 1, PwC estimate that a 15\% nominal increase in licence fee revenue over a 5-year period would lead to a net increase in the level of GDP of $£ 319$ million in 2021/22 relative to a baseline of no change in the BBC's licence fee revenues. In Scenario 2, PwC estimate that a $25 \%$ nominal decrease in licence fee revenue over a 5-year period would lead to a net decrease in level of GDP of $£ 630$ million in 2021/22. The study argues these changes would be driven by two effects: first, the BBC and other TV providers' spend; second, changes in household spend if the licence fee were to increase or decrease. The consequences at different levels depend on the scenario. PwC estimates that Scenario 1 (licence fee revenues increased by $£ 558$ million) would lead the BBC to invest $£ 347$ million more in TV, and other TV providers to generate $£ 304 \mathrm{~m}$ less in revenues, for an overall net growth in the sector of $£ 43$ million, and that the net effect on the total UK economy, taking into account increased BBC spend, decreased spend by other TV providers, and households spending more on licence fee payments and less on other expenditures, would be $+£ 545$ million. In Scenario 2 (licence fee revenues decreased by $£ 931$ million) PwC estimates this would lead the BBC to invest $£ 704$ million less in TV, and other TV providers to generate $£ 540$ million more in revenues, for an overall net effect in the sector of $-£ 164$ million, and that the net effect of the total UK economy, taking into account increased BBC spend, decreased spend by other TV providers, and households spending more on licence fee payments and less on other expenditures, would be negative at $-£ 1076$ million. As PwC discuss in an appendix, the analysis is highly sensitive to the specific assumptions made. With slightly altered assumption about the impact on subscription television, for example, the net negative impact in Scenario 2 would be $£ 141$ million rather than $£ 1076$ million.

A further study from the United Kingdom is a response by the BBC Trust to the British Government in the context of the 2016 renewal of the BBC charter (KPMG 2015). It combines historical data and econometric analysis to assess how the BBC may have affected commercial competitors between 2002 and 2014. Specifically, the study focuses on three markets: entertainment television broadcasting, news 
television broadcasting, and the market for local print newspapers. The historic data serves to track actual changes over time, the econometric analysis to control for other factors that may have influenced the outcomes. The study has the distinct advantage that it is a dynamic analysis: that is, it assesses the actual, measurable impact of increases or decreases in the scale and scope of the BBC's activities on commercial competitors, rather than sticking to associations (like BBC 2013) or relying on counterfactuals (like Barwise and Picard 2014). It concludes that there is no clear evidence that any increase or decrease in the level of BBC activity has resulted in a decline/increase in commercial broadcasters' viewer hours or their revenues, or in local newspapers' readership or revenues. However, the report underlines that these findings only apply to the examined time period. The outcome might be very different if the $\mathrm{BBC}$ were to increase or decrease its activities by a larger degree in the future. The report notes that the findings of these three studies, namely that public service media do not crowd out commercial revenues, are in line with the conclusions of older research (for an overview see KPMG 2015, p. 14). ${ }^{6}$

The most recent study of the United Kingdom that we have identified is by two consultancies, Oliver \& Ohlbaum and Oxera Consulting (2016), who were comissioned by the Department for Culture, Media and Sport to assess the market impact and distinctiveness of $\mathrm{BBC}$ television, radio, and online sevices as part of the $\mathrm{BBC}$ charter review. The study summarise 20 years of market impact research in the United Kingdom and furthermore explores how different degrees of distinctiveness in the BBC's mainstream and high-reach services-BBC One, BBC Two, Radio 1, Radio 2, Radio 5 Live, and BBC Online-can create diverging levels of market impact. The review part shows how previous research has shown while "the BBC takes audience share from the United Kingdom commercial TV, radio and online sectors ... at a broad level, the impact on domestic commercial rivals is limited" (p. 10), most importantly because audience share loss for private sector media is not one-to-one in line with the BBC's gain; potentially reduced advertising and subscription revenues for private sector media are not directly proportionate to any audience share loss because commercial audience losses also increase the market price of advertising to some extent and premium subscription services remain distinct from BBC offerings (e.g. advertising and audience demand is far from completely elastic). The original part of the study is doubly hypothetical, in that (1)

\footnotetext{
${ }^{6}$ Reviews commissioned by the Norwegian government (Andersen 2014) and the Swedish government (Myndigheten för Radio och TV, 2015) have arrived at similar conclusions. A nonempirical report commissioned by the UK News Media Association and produced by Oliver and Ohlbaum (2015) similarly argues that there is no crowding-out effect now. However, the report cautions against the potential risk of future crowding out if BBC investments in online news increase further.
} 
the analysis is counterfactual, like that of Barwise and Picard (2014) and (2) the object is to assess what market impact a different (rather than the actually existing) BBC might have. It includes detailed market impact assessments (MIAs) across television, radio, and online (including news and on-demand). The approach is based on the formal MIAs as they have been conducted in the United Kingdom since 2003/2004. It combines a counterfactual quantitative assessment (akin to Barwise and Picard 2014) focused on audience/revenue substitution effects as well as an assessment of broader market structures and dynamic issues such as redeployed funding, changes in service mix and positioning, and impact on the supply chain. Overall, Oliver \& Ohlbaum and Oxera Consulting (2016) argue that greater distinctiveness in the BBC's mainstream services could have a positive impact not only on the commercial market but also on the net market. They suggest that if the BBC retained its current resource and investment level but repositioned to offer less entertainment, soft news and sports, this would somewhat decrease its audience reach and free up resources to increase investment in more diverse original programming, harder news, and background and analysis, while helping some private sector media companies to capture larger audiences and generate more revenues. They arrive at this through a series of counterfactual analysis and suggest that a "more differentiated BBC", with the current level of resources and investment, could bolster commercial revenues across television (by between $0.9 \%$ and $1.1 \%$ ), radio (4.5\% to $8 \%$ ), and online news providers (by between $0.8 \%$ and $2.1 \%$ ) by repositioning its offerings. The study is a detailed analysis starting from an empirical baseline and across sectors. Like Barwise and Picard's (2014) study the analysis is primarily counterfactual, unlike the more robust dynamic analysis carried out by KPMG (2015) on the basis of historical data. Though the study does cover online news, the authors emphasise their limited ability to estimate the market impact of the BBC on pay television and many online services - large and growing parts of the private sector media industry, and sectors with considerable international spillover.

Outside the United Kingdom, the only evidence-based recent study we have identified is from Norway, "Konkurransemessige virkninger av noen utvalgte NRKtjenester" (Competitive impact of selected NRK services) (SNF 2015). The study was commissioned by the Norwegian Ministry of Culture and conducted by a team from SNF-Centre for Applied Research, a contract research organisation affiliated to the Norwegian School of Economics. The purpose of the study was to assess the market impact of select services provided by the licence fee funded public service media organisation NRK. The analysis combines (1) a content analysis, to assess how different the NRK offerings are from private sector media, (2) an analysis of web traffic to assess the competitive dynamics between public service media and private 
sector media, and (3) a survey of media users to capture the audience's perspective on NRK's position relative to private sector media. The bulk of the analysis focuses on online news, a topic of which Oliver \& Ohlbaum and Oxera Consulting (2016) offers the only other analysis, and especially regional and local news. The authors present a differentiated analysis considering national versus regional/local news separately and examining different regions of Norway to capture the impact of NRK in different contexts. They find that public service news in Norway is relatively different from that provided by large, nationally oriented broadsheet and tabloid newspaper websites and that "there is little reason to believe that nrk.no by being present in the market limits the ability of other nationally oriented news sites to charge for online news" (SNF 2015, p. 6). At the national level, the authors highlight that while nrk.no is popular in Norway, it is far from the only free website for news, and that in a very competitive market for online news from different providers, media users in Norway are likely to continue to have several free alternatives even if one imagines a market without NRK. Furthermore, web traffic data suggests that private sector media compete more with each other than with NRK. At the regional/local level, the detailed analysis suggests that (1) NRK content has only limited overlap with local news sources, in that NRK primarily provides regional news rather than local news, (2) that web traffic suggests there is limited direct competition between regional NRK sites and local news sites, and (3) that the survey data suggests that media users do not see NRK and other news sites as alternatives, but as supplementary to each other. While the authors underline that assessing the impact of some of the more specialised public media online services is hard, they conclude that NRK is not the main or most important competitor for private sector media in national news and local news, and that the challenges faced by companies in these sectors have more to do with a generally more competitive battle for attention and advertising and specifically with competition from large international technology companies than with public service media. (A similar point has been made by Enders Analysis (2015) in the United Kingdom, in a report that discussed the $\mathrm{BBC}^{\prime}$ 's effect on regional and national news providers. The paper argues that the general effect of the internet on the business model for newspapers is far more important than the BBC's activities.)

In the German context, a report by Dewenter and Haucap (2009) commissioned by the Verband Privater Rundfunk und Telemedien e.V. ("private broadcasting and telemedia organisation") that discusses the market impact of public service online offerings. On the basis of a theoretical discussion, they develop a scheme for evaluating public service value in the context of existing private sector offerings. The scheme suggests considering the number of producers for a certain topic category on 
the market, the general competitive situation, the societal relevance of the topic, the ability of the user to verify the information, and the market impact of public service media in static and dynamic terms. Finally, they apply this procedure for 12 topic categories. ${ }^{7}$ In general, they find high competition and a high number of offerings across the topic categories analysed. They see public service content as adding public value for regional and supraregional news as well as partly for economic and financial content, since those categories are, according to them, of high societal relevance and the private sector alone is unlikely to ensure optimal provision. In some cases, they also see a legitimate place for public service provision aimed at children. The exact weighting and measurement of some of the variables in their scheme-such as societal relevance-remains vague.

Overall, the majority of the publicly available empirical studies we have identified are from the United Kingdom. The comparative study published as BBC (2013) underlines the importance of caution when generalising findings from one context. While that study identifies a group of countries with a similar, seemingly positive, association between strong private sector media and strong public service media (United Kingdom, Norway, Denmark, and Australia) and group of countries with comparatively low scores for both (like Portugal and Italy), it also identifies a group of countries with a weaker correlation between public service media strength and private sector media strength. The United States is one clear outlier in this case, as mentioned earlier, but so is Germany, which has a strong public service broadcasting sector but a comparatively weak commercial sector.

\section{Limitations}

Some of the studies discussed above rely on cross-sectional analysis of data from one moment in time, making it hard to determine whether associations identified indicate causal relationships, i.e. impact. Others are based on counterfactual modelling that, while starting from an empirical baseline, remains theoretical and relies on a large number of assumptions that influence results. The more granular, dynamic, and data-based empirical studies like KPMG (2015) and SNF (2015) tend to find little or no impact, but rightly caution that their findings are likely to be specific to the particular time periods and situations analysed, and that one cannot necessarily generalise from these. Finally, there are only a few limited studies that deal with online market impact, and these tend not to take into account how the

\footnotetext{
7 The categories are: fictional audiovisual on-demand content, supraregional news, sports, entertainment and lifestyle, economics and finance, regional and local news, fictional entertainment and content for children, car and traffic, weather, travelling, family, leisure and health, or computer, telecommunication and consumer electronics.
} 
wider media environment is changing as global players become more important across many national markets.

\subsection{Public service media impact on investments in original content}

Several of the studies mentioned above also in part investigate the impact of public service media on investments in original content, both overall, and by private sector media specifically.

The international comparative study commissioned by the BBC (2013) finds positive correlation between investments in original programming per capita by the lead public television channel versus the lead private television channel. The highest levels of per capita investment in originations, out of 10 countries, are found in the United Kingdom, Denmark, and Norway. In line with the 'race to the top' thesis, it is hypothesised that public service commitment to investing in original content for competitive reasons has led private sector media to also invest more than they would otherwise have done.

Barwise and Picard (2014) conclude in their study that if there were no BBC, total content investments would decrease by $5 \%$ to $25 \%$. Investments in first-run UK content would also decline by $25 \%$ to $50 \%$, although commercial broadcasters would invest more. These conclusions thus differ from the 'race to the top' idea in that they argue that private sector media would invest more in the absence of public service media, but they see the net impact of public service media on overall investment in original content as clearly positive.

The above-mentioned PwC (2015) report also estimates the changes in investment in first-run UK-originated TV content spend of Scenario 1 (increased licence fee revenues) and Scenario 2 (decreased licence fee revenues). On the basis of their assumptions, the study suggests increased investment of $£ 221$ million if the licence fee increases by $£ 558$ million, and decreased investment of $£ 334$ million if it decreases by $£ 704$ million. The report notes "it is difficult to predict how other TV providers will change their spend on first-run United Kingdom TV content" in each scenario, as some of the assumptions that have to be made cannot be based on empirical evidence.

Oliver \& Ohlbaum and Oxera Consulting (2016) and the Norwegian SNF (2015) study only indirectly address the issue of investment in original content, but both argue that the precise nature of the content public service media invest in, and the degree to which it competes with commercial alternatives directly and/or serves as a like-for-like substitute with them, shapes public service media's impact on overall investment in original content. Where public service media content is 
simultaneously popular enough to serve its public service mission and clearly distinct from private sector media offerings, there is less likely to be crowding out.

In terms not only of levels of investment, but also diversity of output, several studies have examined the role of public service media. The BBC (2013) cited above identifies a strong positive correlation between diversity of schedule (operationalised as proportion of key public service genres ${ }^{8}$ ) in the main public versus the main private television channels - that is, the more diverse one kind of channel is, the more likely other kinds of channels are to also have diverse offerings. Along similar lines, Barwise and Picard (2014) find that most viewers in the United Kingdom would suffer a reduction in diversity of choice if there were no BBC.

Two further academic studies analyse the impact of public service media on diversity of supply. In a study of eight European countries using data from the late 1980s and 1990s, van der Wurff (2005) investigated how provider competition, concentration and public service media influence diversity of programme supply in television markets. The study concludes that public service media increase diversity of programme supply above competitive market levels. A study of ownership and the provision and consumption of radio news in the United States by Waldfogel (2011) points in a similar direction. His findings show that in markets with proportionally more commercial news stations there are relatively fewer news stations and less diversity in news. However, due to the large number of commercial players in the United States, public news stations only have larger marginal impacts on available news diversity (formats) and news listening than commercial news stations.

\section{Limitations}

The limitations here as the same as those discussed above. Some of the studies discussed above rely on cross-sectional analysis of data from one moment in time, making it hard to determine whether associations identified indicate causal relationships, i.e. impact. Others are based on counterfactual modelling that, while starting from an empirical baseline, remains theoretical and relies on a large number of assumptions that influence results. The more granular, dynamic, and data-based empirical studies like KPMG (2015) and SNF (2015) tend to find little or no impact, but rightly caution that their findings are likely to be specific to the particular time periods and situations analysed, and that one cannot necessarily generalise from these. Finally, there are only a few limited studies that deal with online market

\footnotetext{
8 Arts, humanities and science programmes; children's programmes; education; religion; music; news and information. For pragmatic research reasons the main genres (entertainment, fiction, sport) were not counted as key public service genres despite contributing to the public remit (BBC, 2013, p. 9).
} 
impact, and these tend not to take into account how the wider media environment is changing as global players become more important across many national markets.

\subsection{Public value tests}

Since 2007, the United Kingdom has operated a system of PVTs to assess the impact of proposed new BBC services before they are rolled out. The PVTs only apply to the $\mathrm{BBC}$, not to other parts of the British public service system. The PVTs are currently administered by the BBC Trust and Ofcom and applied to new services proposed by the BBC Executive. (The Government's recently published White Paper on the renewal of the $\mathrm{BBC}$ charter suggests that this arrangement is likely to change in the future.) PVTs were developed to institutionalise pre-assessment of market impact which in the past happened on a more ad-hoc basis (with the Barwise Report, the Graf Report, and the Gardam Report) and to ensure that the development of British public service broadcasting was compliant with EU norms and regulations relating to state aid. ${ }^{9}$

The PVT approach has been adopted in various ways across Europe as a way to measure the public worth and possible market impact of planned publicly funded media services. A number of academic publications discuss PVTs across several European countries (Collins, 2007; Dewenter \& Haucap, 2009; Humphreys, 2010; Moe, 2010; Donders \& Moe, 2011). Most of these studies are, however, focused on policy and political issues around PVTs, and do not present empirical studies of the actual political, social, and/or market impact of public service. They thus fall outside the scope of this report. ${ }^{10}$ As of September 2015, the Swedish Myndigheten för Radio och TV (2015) reported that 14 out of 30 European countries covered operate with some version of PVT to assess new proposed public service initiatives before they are launched. In most countries, the PVT is initiated by regulators or public service

\footnotetext{
${ }^{9}$ As the European Commission's 2009 Communication from the Commission on the application of State aid rules to public service broadcasting made clear, the "definition of the public service mandate by the Member States should be as precise as possible. It should leave no doubt as to whether a certain activity performed by the entrusted operator is intended by the Member State to be included in the public service remit or not".

${ }^{10}$ For example, in the book entitled Exporting the Public Value Test: The Regulation of Public Broadcasters' New Media Services Across Europe (Donders and Moe 2011), academics as well as stakeholders from across Europe describe the implementation of the PVT in different European countries and identify differences. They discuss prospects and pitfalls of the implementation process and give recommendations for the governance of public service media. Although the aim of the publication is not to analyse the problem of crowding out, it does include an empirically based example for Germany's public service broadcaster ZDF. The Goldmedia and Salans (2010) market analysis calculated the eventual profit of ZDF's theoretical market exit for the market competitors as $0.44 \%$ of market volume. Accordingly, their market definition is restricted to the online advertising market, excluding mobile applications and pay services.
} 
providers themselves. In Finland other stakeholders can request a PVT. As is clear from Table 1, most countries have conducted only a limited number of PVTs (the exception being Germany). 7\% of the 70 PVTs conducted up to September 2015 across these 14 countries have resulted in service being rejected.

\begin{tabular}{|c|c|c|c|}
\hline Country & Public value test & Number of tests & $\begin{array}{c}\text { Results } \\
\text { (approved/rejected/pending) }\end{array}$ \\
\hline Belgium & Yes & 0 & $0 / 0 / 0$ \\
\hline Denmark & Yes & 0 & $0 / 0 / 0$ \\
\hline Bulgaria & No & - & - \\
\hline Cyprus & No & - & - \\
\hline Estonia & No & - & - \\
\hline Finland & Yes & 2 & $2 / 0 / 0$ \\
\hline France & No & - & - \\
\hline Greece & No & - & - \\
\hline Ireland & Yes & 3 & $2 / 0 / 1$ \\
\hline Italy & No & - & - \\
\hline Croatia & No & - & - \\
\hline Iceland & Yes & 0 & $0 / 0 / 0$ \\
\hline Latvia & Yes & 0 & $0 / 0 / 0$ \\
\hline Lithuania & No & - & - \\
\hline Luxemburg & No & - & - \\
\hline Malta & No & - & - \\
\hline Netherlands & Yes & 7 & $1 / 5 / 1$ \\
\hline Norway & Yes & 2 & $2 / 0 / 0$ \\
\hline Poland & No & - & - \\
\hline Portugal & Yes & 1 & $1 / 0 / 0$ \\
\hline Rumania & No & - & - \\
\hline Slovakia & No & - & - \\
\hline Slovenia & No & - & - \\
\hline Spain & No & - & - \\
\hline United Kingdom & Yes & 5 & $3 / 1 / 1^{*}$ \\
\hline Sweden & Yes & 0 & $0 / 0 / 0$ \\
\hline Czech Republic & No & - & - \\
\hline Germany & Yes & 44 & $43 / 1 / 0$ \\
\hline Hungary & Yes & 0 & $0 / 0 / 0$ \\
\hline Austria & Yes & 6 & $4 / 1 / 1$ \\
\hline
\end{tabular}

Table 1. Adopted from Myndigheten för Radio och TV (2015). The data is from September 2015.

* The pending decision in the United Kingdom has since resulted in a rejection.

Below, we will consider the methodology and data used in the United Kingdom and Germany for PVTs in greater detail as examples of how PVTs are conducted. We 
discuss these PVT approaches here as examples of evidence-based assessments of the impact of public service media, but we should underline that each test is very specific to the particular context and the particular service being tested. No generalisable conclusions therefore arise from these particular tests, but they are worth examining because of the method and data involved.

\subsubsection{The British public value test}

The British PVT approach involves two assessments: (1) a public value assessment (PVA), which assesses the likely public value of the proposed service; (2) a market impact assessment (MIA), which assesses the extent of any likely impact on markets relevant to the proposed change. The BBC Trust is responsible for the PVA and the integrated media regulator Ofcom is responsible for the MIA (see BBC Trust 2012). On the basis of the two assessments, the BBC Trust will then evaluate whether any likely adverse impact on the market is justified by the likely public value of a new proposed service before approving it (as proposed or in an amended form). The BBC Executive must seek approval for changes or new services that require an amendment to a service licence, represent a potentially significant change to the BBC's United Kingdom Public Services (such as starting a new service), or introduce a potentially significant new non-service activity or propose a potentially significant change to an existing one. The BBC Trust will consider proposals submitted by the BBC Executive but can also require the Executive to provide information on changes that have not been submitted.

The PVA part of the assessment considers the value which the proposed change would deliver through its contribution to the BBC's public purposes as defined in its charter. The methodological approach will be defined on a case-by-case basis by the BBC Trust, but generally focuses on indicators of quality, reach, impact, and value. Indicators can include forecasts of demand, results from trials or pilots, qualitative and quantitative studies including consumer research and deliberative juries, internal and external market analysis, independent expert advice, evidence of impact on particular parts of the audience, and the analysis of such impact (especially as regards, where applicable, compliance with the public sector equality duty). In practice, PVA have relied primarily on evidence submitted by the BBC Executive, but the BBC Trust can commission its own research as well.

The MIA part of the assessment evaluates the likely impact of the proposed service or activity on the wider market, both present and future. The assessment is carried out by Ofcom on the basis of a methodology agreed upon by Ofcom and the BBC Trust in each specific case. The aim is to considers both the direct impact on consumers and producers of other services, for example in terms of price and choice, 
and the likely impact on competition and market development, which will affect consumer and citizen interests in the longer term. As Ofcom explains in their general description of their approach to MIAs, the aim is to evaluate both static and dynamic effects on services and markets and to adopt a total welfare approach, assessing changes in welfare for both citizens/consumers and producers, including effects on those that compete with the proposed service as well as those in related upstream (e.g. suppliers), downstream (e.g. buyers), or two-sided (e.g. advertising) markets. ${ }^{11}$

There have been eight formal MIAs in the United Kingdom to date. ${ }^{12}$ Three where carried out before the BBC Trust and Ofcom were given joint responsibility for PVTs in 2007 (the Barwise Review, the Gardam Review, and the Graf Review, all in 2004). Five have been carried out since, of the BBC's HDTV proposals; BBC Digital Gaelic proposals (BBC Alba); the BBC's on-demand service proposals (iPlayer for TV and radio on-demand and podcasting services); the $B B C^{\prime}$ 's ultra-local video proposals (mainly online news and information services); the BBC's changes to BBC Three and CBBC; and the introduction of a BBC One +1 service proposal. Two of the five PVTs led to the proposal being rejected (the ultra-local video proposal and the BBC One+1 proposal, in part on the basis of their expected market impact). In this light, the criticism that the UK PVT consisted of little more than a 'ritual of verification' seems misguided. ${ }^{13}$

Each MIA has adopted a different methodology, but, looking back, Oliver \& Ohlbaum and Oxera Consulting (2016) identifies the most important tools used: (1) Historic time series data of BBC performance versus commercial sector performance at the audience, output, revenue, or content investment level reviewed to test for any

\footnotetext{
${ }^{11} \mathrm{http}$ ://stakeholders.ofcom.org.uk/broadcasting/bbc-trust/bbc-mias/statement/. The individual MIAs conducted by Ofcom can be accessed at http://stakeholders.ofcom.org.uk/broadcasting/bbc-trust/bbcmias/

${ }^{12}$ The discussion here focuses purely on the tests applied to public services. In 2008 there was consideration by the UK Competition Commission of a commercial video on demand joint venture between BBC Worldwide (the BBC's commercial arm), Channel 4, and ITV, in a partnership known as Project Kangaroo. The Commission's final report published in February 2009 decided that the project would be a threat to competition in a developing market and should be stopped. See press release at http://webarchive.nationalarchives.gov.uk/20140402141250/http://www.competitioncommission.org.uk/assets/competitioncommission/docs/pdf/non-inquiry/press_rel/2009/feb/pdf/0509.pdf and full report here at http://webarchive.nationalarchives.gov.uk/20140402141250/http://www.competitioncommission.org.uk/assets/competitioncommission/docs/pdf/noninquiry/rep_pub/reports/2009/fulltext/543.pdf

${ }^{13}$ For a description of the early approach adopted by the BBC Trust and the application of the PVT to the first three cases, see "Public Value in Practice", by Dianne Coyle with Christopher Woolard (BBC Trust 2007). See also the exhaustive material for all the individual PVTs on the BBC Trust website at http://www.bbc.co.uk/bbctrust/governance/tools_we_use/public_value_tests.html
} 
evidence of audience or revenue substitution or positive/negative feedback of BBC investment levels on sector investment levels in terms of content or platforms. (This is the main approach adopted in KPMG 2015 discussed above.) (2) Cross-sectional data between national media markets or between regional markets in the United Kingdom can be used for the same purpose, to test for a link between the size, funding, or output mix of publicly funded BBC activity and commercial sector activity in one geographic market versus another. Cross-sectional data between different BBC genre output and performance versus commercial rivals' output and performance can also be used to test whether the BBC is squeezing the commercial sector out of specific areas of output. In both cases, the problem is how to take into account non-BBC factors and change over time or between markets so as to isolate the impact of public service media specifically from other factors such as the economic cycle or changes in the media environment-and so move from simple correlation to a better understanding of attributable causation. A third approach is (3) event analysis. As Oliver \& Ohlbaum and Oxera Consulting (2016) explain, "picking a short period of large-scale change to either BBC or commercial services, during which other factors either did not change or changed in a predictable way, can help isolate the impact without the need for time series data over a long horizon, or large amounts of cross-sectional data on all potentially explanatory variables." This, however, has not been used in practice, and it remains difficult to control for other factors (as discussed above). Hence, Ofcom has occasionally relied instead on audience research, content analysis, and/or surveys as an indicator of likely market impact, including studies based on (1) output distinctiveness, (2) socio-demographic differentiation, (3) market behaviour segmentation, (4) consumer surveys and/or (5) industry surveys. These approaches provide a way of assessing the character of content and audience engagement and what competitors think of a proposed new service, but is at best an indirect measure of market impact. Finally, Ofcom has also relied on competitive response and dynamic scenario modelling to develop models of how private sector media might respond to changes in public service media provision. These can be backed up by interviews and formal models, but are often presented as response scenarios, often with no specific view as to which scenario is more likely. Instead, they present a range of outcomes or a simple average of outcomes as the most likely view. This is the method deployed by Barwise and Picard (2014) in their independent study above.

\subsubsection{The German public value test}

The German PVT approach is called the Drei-Stufen-Test (three-step test). It was introduced with the 12th Interstate Treaty on Broadcasting and Telemedia (RStV), 
which was signed in 2008 and came into force on 1 June 2009. The treaty was the first to explicitly include what the Germans term "telemedia" among the public broadcasters' range of services (RStV Section 11a, I). While the term is not directly defined it includes, among other platforms, the online activities of ARD (and its regional affiliates), ZDF, and Deutschlandradio. In response to private sector media's concerns over what public service media in Germany might offer online, the treaty allowed them only to publish "programs and telemedia related to a specific program. ... press-like offerings unrelated to the program shall not be permitted" (RStV Section 11d, II No. 3). Unlike preceding treaties, which limited public service media to investing no more than $0.75 \%$ of their budget in online offerings, the 12th treaty no longer caps investment in online services, and gives ARD and ZDF great freedom in allocating their budgets across platforms (Weberling 2011).

The German PVT test requires public service media organisations justify new proposed online services and other "telemedia offerings" to the relevant broadcasting council in terms of three steps (RStV, Section $11 \mathrm{f}(4))$ :

1. To what degree does the offer conform to the democratic, social and cultural needs of society?

2. To what degree does the offer make a qualitative contribution to media diversity and competition?

3. What are the financial costs and does the offer deliver value for money?

On the basis of an assessment of these three steps, the decision to accept a new or modified offer must be passed by a two-thirds majority of all votes cast by the members present at a meeting of the relevant broadcasting council (RStV Section 11f, $\mathrm{VI})$.

In the 12th RStV, the Länder agreed that the test should be applied not only for new online/telemedia services, but also retrospectively for existing ones. This involved a large number of tests concluded in 2010, where the vast majority of online services from all the various German public service broadcasters were approved by their relevant broadcasting councils with very similar decisions and only a few minor changes, for example in terms of how long digital versions of broadcast programmes are available on demand (Weberling 2011).

An independent market assessment is part of evaluating whether the public value that might be created outweigh the likely negative impact on other market actors. The German MIAs refer to the second step outlined above and are in practice at the core of the three-step test, the question whether and how a proposed public service media offering will impact media diversity and qualitative competition overall. Although the online offerings of German public service media do not compete with 
private sector media in direct economic terms (advertising and sales), they compete for the attention and time of the user, and offer content and services free at the point of consumption. In principle, this could lead to lower advertising revenues or lower revenues from paid content for private media.

In detail, the broadcasting councils have agreed on the following information for market assessments (for a comprehensive description see Woldt, 2011, pp. 70-73):

1. Identification of the relevant economic markets for the telemedia offer in discussion.

2. Identification of relevant competing offers.

3. Static analysis of market and competition in the market described above for the telemedia offer in discussion.

4. Dynamic analysis of market and competition; here, a simulation should show how a market exit of the public service telemedia offer or a market entrance (in case of a new offer) would impact on an existing market. In particular, the consequences for the user should be taken into account.

5. Documentation and presentation of findings.

However, this is just a rough structure for the market assessments. How the different assessors fill in the structure and which methods they use is up to them. There is no one uniform approach. A broader methodological discussion has arisen around the question of whether the method of Hypothetical Monopolist testing, suggested by the European Commission, is adequate to identify relevant markets or underestimates them (see e.g. Dewenter \& Haucap, 2009). While some assessors relied on this method (e.g. European Economic \& Marketing Consultants), others developed alternative methods. For example, Deloitte Consulting conducted surveys and asked users which websites they would go to if there was no tagesschau.de any more (similar to one of the methods used by SNF (2015) as discussed above). Furthermore, they interviewed experts and stakeholders (similar to one of the methods used by Ofcom). Others, e.g. aserto, relied on detailed qualitative descriptions of the telemedia offering in discussion and identified relevant markets and competitors in this way (Woldt, 2011, p. 72).

For the static analysis mostly usage data was taken into account. The page impressions of the online offering under consideration were related to those of relevant private competitors. In some cases the usage data was complemented by surveys on e.g. the intensity of use or valuation of the user. In some cases qualitative comparisons between the online offers under discussion and competitive offers were conducted (Woldt, 2011, pp. 72-73). For the dynamic analysis the reach of the online offers in question as well as the amount of usage (e.g. page views or visits) were 
taken into account and related to common advertisement revenues as well as paid content offers. Finally, consequences for neighbouring markets were analysed, e.g. for the infrastructure market (Woldt, 2011, p. 73).

Overall, the methods and date used for MIAs in Germany are at least as varied as those used in the United Kingdom. Of the 44 PVTs identified by Myndigheten för Radio och TV (2015), 43 have resulted in the offerings being approved (sometimes with minor modifications). Only one service has been rejected so far, an online radio streaming service called "JUMP Interactiv" from Middle Deutsche Rundfunk (MDR) aimed at providing news and current affairs for young audiences (MDR 2010).

\section{Limitations}

Some PVT analyses present detailed, empirically based assessments of several factors including market impact. Others are less empirically based. There is no uniform approach, not at the national level, and certainly not across Europe. The time it takes to conduct PVTs, and how costly they are, can vary greatly. While the most detailed studies can be impressive, they are also very specific and very context dependent, and thus do not allow for general conclusions about the likely market impact of public service media overall. 
Market impact-table of sources

\begin{tabular}{|c|c|c|}
\hline Study & Method & Relevant conclusions \\
\hline $\begin{array}{l}\text { Barwise and Picard } \\
\text { (2014) }\end{array}$ & $\begin{array}{l}\text { Counterfactual scenario of the } \\
\text { impact on the UK media market } \\
\text { if there were no BBC. }\end{array}$ & $\begin{array}{l}\text { The counterfactual analysis suggests that the } \\
\text { extent of crowding out, insofar as it exists at all, } \\
\text { is limited. }\end{array}$ \\
\hline & $\begin{array}{l}\text { The authors produced } \\
\text { 'optimistic' and 'pessimistic' } \\
\text { scenarios based on assumptions } \\
\text { around commercial operators' } \\
\text { subscription income, advertising } \\
\text { income and investment } \\
\text { (determined as a proportion of } \\
\text { revenues and flexed for } \\
\text { optimistic and pessimistic } \\
\text { scenarios). }\end{array}$ & $\begin{array}{l}\text { In addition, it finds that without the presence } \\
\text { of the BBC: industry revenues, although } \\
\text { uncertain, might decline; content investment } \\
\text { fall by } 5-25 \% \text {; and first-run content investment } \\
\text { might decline by } 25-50 \% \text {. }\end{array}$ \\
\hline BBC (2013) & $\begin{array}{l}\text { Cross-sectional analysis of } \\
\text { television markets in } 14 \\
\text { countries. } \\
\text { Study assesses how commercial } \\
\text { market outcomes (a composite } \\
\text { measure of revenues per capita, } \\
\text { investment per capita in original } \\
\text { programmes, and schedule } \\
\text { diversity) are associated to public } \\
\text { service media strength (a } \\
\text { composite of public funding per } \\
\text { capita, investment per capita in } \\
\text { original programmes, and } \\
\text { schedule diversity). }\end{array}$ & $\begin{array}{l}\text { Statistically significant positive correlation } \\
\text { between commercial market outcomes and } \\
\text { public service media strength in most areas } \\
\text { and most countries. }\end{array}$ \\
\hline $\begin{array}{l}\text { Dewenter and Haucap } \\
\text { (2009) }\end{array}$ & $\begin{array}{l}\text { Based on a theoretical discussion, } \\
\text { the study develops a scheme for } \\
\text { evaluating public service value in } \\
\text { the context of existing private } \\
\text { sector offerings based on topic } \\
\text { category, the competitive } \\
\text { situation, the societal relevance of }\end{array}$ & $\begin{array}{l}\text { Testing the scheme, the authors find high } \\
\text { competition and a high number of offerings } \\
\text { across the topic categories analysed and only } \\
\text { see public service content as adding public } \\
\text { value for regional and supraregional news as } \\
\text { well as partly for economic and financial }\end{array}$ \\
\hline
\end{tabular}


the topic, the ability of the user to verify the information, and the market impact in static and dynamic terms of public service media.

KPMG (2015)

Oliver \& Ohlbaum and Oxera Consulting

(2016)

PwC (2015)
Historical and econometric analysis that assesses possible crowding-out effects of commercial operators by the BBC on three markets between 2002 and 2014: entertainment television broadcasting, news television broadcasting, and local print newspapers.

Reviews existing market impact research in the UK and presents a double-counter-factual analysis of what the possible market impact of a different and more distinct $\mathrm{BBC}$ might be.

Uses counterfactual modelling based on a computable general equilibrium model of the UK economy to assess impact across not only the media sector, but also the UK economy more broadly based on two scenarios: (1) a nominal increase in licence fee revenue of $15 \%$ by $2021 / 22$, implemented gradually and (2) a nominal decrease in licence fee revenue of $25 \%$ by $2021 / 22$, implemented gradually. content plus in some cases public service provision aimed at children.

No clear evidence that any increase or decrease in the level of BBC activity has resulted in a decline/increase in commercial broadcasters' viewer hours or their revenues, or newspapers readership or revenues. However, these findings apply only to the time period under investigation and cannot be extrapolated to future scenarios.

Finds that while the BBC takes audience share from private sector media, the impact on commercial rivals is limited. Argues that a more distinct $\mathrm{BBC}$ with the same resource base might lead to somewhat higher revenues for private sector television, radio, and online news providers.

In Scenario 1, PwC estimate that a $15 \%$ nominal increase in licence fee revenue over a 5-year period would lead to a net increase in the level of GDP of $£ 319$ m in $2021 / 22$ relative to a baseline of no change in the BBC's licence fee revenues. In Scenario 2, PwC estimate that a $25 \%$ nominal decrease in licence fee revenue over a five year period would lead to a net decrease in level of GDP of $£ 630 \mathrm{~m}$ 2021/22. Furthermore, PwC estimates that Scenario 1 would lead to overall net growth in the TV sector of $£ 43 \mathrm{~m}$, and that the net effect of the total United Kingdom economy would be $+£ 545 \mathrm{~m}$. In Scenario 2 PwC estimates this would lead to an overall net effect in the TV sector of $-£ 164 \mathrm{~m}$, and that the net effect of the 
total United Kingdom economy would be negative at $-£ 1076 \mathrm{~m}$.

SNF (2015)

van der Wurff (2005)*

Waldfogel (2011)
Multi-method study to assess the market impact of select services provided by the licence fee funded public service media organisation NRK. The analysis combines (1) a content analysis, to assess how different the NRK offerings are from private sector media, (2) an analysis of web traffic to assess the competitive dynamics between public service media and private sector media, and (3) a survey of media users to capture the audience's perspective on NRK's position relative to private sector media.

Data analysis of market structure, market conduct (defined as channel programming) and market diversity in Finland, France, Germany, Greece, Italy, the Netherlands, Spain and the UK for the late 1980s and 1990s. Hypotheses are tested on the market as well as on the channel level, when appropriate.

Data analysis of available news stations and listening, by format. These data are combined with market-level demographic information (population, income, etc.) to explore ownership and the provision and consumption of radio news in the US.
Findings see NRK not as the main or most important competitor for private sector media in national news and local news. Challenges faced by companies in these sectors have more to do with a generally more competitive battle for attention and advertising and specifically with competition from large international technology companies than with public service media.

Public service media increase diversity of programme supply above competitive market levels.

$$
\begin{aligned}
& \text { In markets with proportionally more } \\
& \text { commercial news stations relatively fewer } \\
& \text { news stations and less diversity in news. } \\
& \text { However, due to the large number of } \\
& \text { commercial players in the US, public news } \\
& \text { stations only with larger marginal impacts on } \\
& \text { available news diversity (formats) and news } \\
& \text { listening than commercial news stations. }
\end{aligned}
$$




\section{References}

Aalberg, T. \& Curran, J. (eds.) 2012. How Media Inform Democracy: A Comparative Approach. New York: Routledge.

Aalberg, T., Papathanassopoulos, S., Soroka, S., et al. 2013. International TV News, Foreign Affairs Interest and Public Knowledge: A Comparative Study of Foreign News Coverage and Public Opinion in 11 Countries. Journalism Studies, 14(3), pp.387406.

Aalberg, T., van Aelst, P. \& Curran, J. 2010. Media Systems and the Political Information Environment: A Cross-National Comparison. International Journal of Press/Politics, 15(3), pp.255-271.

Aarts, K., Fladmoe, A. \& Strömbäck, J. 2012. Media, Political Trust, and Political Knowledge: A Comparative Perspective. In T. Aalberg \& J. Curran, eds. How Media Inform Democracy: A Comparative Approach. New York: Routledge, pp. 98-118.

Albæk, E., van Dalen, A., Jebril, N., \& de Vreese, C.H. 2013. Political Journalism in a Comparative Perspective. Cambridge: Cambridge University Press.

Andersen, L.C. 2014. Offentlige allmennkringkasteres påvirkning på kommersielle medieselskaper - hva sier forskningen?

https://www.regjeringen.no/contentassets/98dcafb6544e4161b32b5c2e8b978d20/NNNO/SVED/OffentligeAllmennkring.pdf

Baek, M., 2009. A Comparative Analysis of Political Communication Systems and Voter Turnout. American Journal of Political Science, 53(2), pp.376-393.

Barwise, P., \& Picard, R.G. 2014. What If There Were No BBC Television? The Net Impact on UK Viewers. Oxford: Reuters Institute for the Study of Journalism. Retrieved from https://reutersinstitute.politics.ox.ac.uk/sites/default/files/What $\% 20$ if\%20there\%20wer e\%20no\%20BBC\%20TV_0.pdf

BBC. 2013. Public and Private Broadcasters Across the World-The Race to the Top. BBC. Retrieved from:

http://downloads.bbc.co.uk/aboutthebbc/insidethebbc/howwework/reports/pdf/bbc_r eport_public_and_private_broadcasting_across_the_world.pdf

BBC. 2015. BBC Annual Report and Accounts 2014/15. Retrieved from: bbc.co.uk/annualreport

BBC Trust. 2007. Public Value in Practice, by Dianne Coyle with Christopher Woolard. Retrieved from:

http://downloads.bbc.co.uk/bbctrust/assets/files/pdf/regulatory_framework/pvt/publi c_value_practice.pdf. 
BBC Trust. 2012. BBC Trust Assessment Processes. Guidance Document.

http://downloads.bbc.co.uk/bbctrust/assets/files/pdf/about/how_we_govern/pvt/asses sment_processes_guidance.pdf

Cappella, J.N. and Jamieson, K.H. 1997. Spiral of Cynicism: The Press and the Public Good. New York: Oxford University Press.

Channel 4. 2015. Britain's Creative Greenhouse. Channel Four Television Corporation Report and Financial Statements 2014. Retrieved from:

http://www.channel4.com/media/documents/corporate/annualreports/C4\%20Annual\%20Report\%202015.pdf

Collins, R. 2007. The BBC and "Public Value." Medien \& Kommunikationswissenschaft, 55(2), 164-184.

Comscore. 2016. U.S. Cross-Platform Future in Focus.

http://www.comscore.com/Insights/Presentations-and-Whitepapers/2016/2016-USCross-Platform-Future-in-Focus

Connolly, S. \& Hargreaves Heap, S.P., 2007. Cross Country Differences in Trust in Television and the Governance of Public Broadcasters. Kyklos, 60(1), pp.3-14.

Connolly, S., Hanretty, C., Hargreaves Heap, S., \& Street, J. 2015. What Makes for Prize-Winning Television? European Journal of Communication, 30(3), pp.267-284.

Curran, J., Iyengar, S., Lund, A.B., and Salovaara-Moring, I. 2009. Media System, Public Knowledge and Democracy: A Comparative Study. European Journal of Communication, 24(1), pp.5-26.

Curran, J., Coen, S., Aalberg, T., and Iyengar, S. 2012. News Content, Media Consumption, and Current Affairs Knowledge. In T. Aalberg \& J. Curran, eds. How Media Inform Democracy: A Comparative Approach. New York: Routledge, pp. 81-97.

Cushion, S. 2012. The Democratic Value of News: Why Public Service Media Matter. Basingstoke: Palgrave Macmillan.

de Vreese, C.H. \& Boomgaarden, H. 2006. News, Political Knowledge and Participation: The Differential Effects of News Media Exposure on Political Knowledge and Participation. Acta Politica, 41, pp.317-341.

Dewenter, R., \& Haucap, J. 2009. Ökonomische Auswirkungen von öffentlich-rechtlichen Online-Angeboten. Marktauswirkungen innerhalb von Drei-Stufen-Tests. Gutachten im Auftrag des VPRT e.V. Baden-Baden.

Donders, K., \& Moe, H. 2011. Exporting the Public Value Test: The Regulation of Public Broadcasters' New Media Services Across Europe. Nordicom. 
DR Medieforskning. 2016. Medieudviklingen 2015.

http://www.dr.dk/NR/rdonlyres/D8F466AE-9EFB-4617-B8CD-

5737425911FD/6140447/medieudviklingen_2015_3.pdf

EBU. 2015. Public Service Media: Contribution to Society. EBU Media Intelligence Service.

EBU. 2016a. PSM Correlations: Links Between Public Service Media and Societal WellBeing. EBU Media Intelligence Service.

EBU. 2016b. Parliamentary Broadcast Services in Europe. EBU Media Intelligence Service.

EBU. 2016c. PSM Investment in European Content. EBU Media Intelligence Service.

Retrieved from: http://www.ebu.ch/files/live/sites/ebu/files/Publications/EBU-

MIS\%20-\%20PSM\%20Investment\%20in\%20European\%20Content.pdf

Enders Analysis. 2015. The BBC, the Press and Online News. Retrieved from http://www.endersanalysis.com/content/publication/bbc-press-and-online-news

Esser, F., de Vreese, C.H., Strömbäck, J., et al. 2012. Political Information Opportunities in Europe: A Longitudinal and Comparative Study of Thirteen Television Systems. International Journal of Press/Politics, 17(3), pp.247-274.

Fraile, M. \& Iyengar, S. 2014. Not All News Sources Are Equally Informative: A CrossNational Analysis of Political Knowledge in Europe. International Journal of Press/Politics, 19(3), pp.275-294.

Goldmedia \& Salans. 2010. Gutachten zu den marktlichen Auswirkungen der ZDFTelemedien. Retrieved from http://www.zdf.de/ZDF/zdfportal/blob/26566102/1/data.pdf

d'Haenens, L., Antoine, F., \& Saeys, F. 2009. Belgium: Two Communities with Diverging Views on how to Manage Media Diversity. International Communication Gazette, 71(1-2), 51-66.

Hamilton, J. 2004. All the News That's Fit to Sell : How the Market Transforms Information into News. Princeton, NJ : Princeton University Press.

Hanretty, C. 2012. Public Service Broadcasting's Continued Rude Health, London: British Academy.

Humphreys, P. 2010. EU state aid rules, public service broadcasters' online media engagement and Public Value Tests: the German and UK cases compared. Interactions: Studies in Communication and Culture, 1(2), 171-184.

Ihlen, Ø., Allern, S., Thorbjørnsrud, K., \& Waldahl, R. 2010. The World on Television: Market-Driven, Public Service News. Nordicom Review, 31(2), 31-46. 
Iyengar, S., Curran, J., Lund., A.B., Salovaara-Moring, I., Hahn, K.S. \& Coen, S. 2010. Cross-National versus Individual-Level Differences in Political Information: A Media Systems Perspective. Journal of Elections, Political Opinion and Parties, 20(3), pp.291-309. Jacobs, L., Hooghe, M., \& de Vroome, T. 2014. Television and Anti-immigrant Sentiments: The Mediating Role of Fear of Crime and Perceived Ethnic Diversity. Paper presented at the ECPR General Conference, University of Glasgow, 3-6 September 2014.

Janowitz, M. 1957. Community Ties in an Urban Setting. Glencoe: Free Press. Jenssen, A.T. 2009. Does Public Broadcasting Make a Difference? Political Knowledge and Electoral Campaigns on Television. Scandinavian Political Studies, 32(3), pp.247271.

Jenssen, A.T., Aalberg, T. \& Aarts, K. 2012. Informed Citizens, Media Use, and Public Knowledge of Parties' Policy Positions. In T. Aalberg \& J. Curran, eds. How Media Inform Democracy: A Comparative Approach. New York: Routledge, pp. 138-158.

Koeman, J., Peeters, A. \& d'Haenens, L. 2007. Diversity Monitor 2005: Diversity as a Quality Aspect of Television in the Netherlands. Communications, 32(1), 97-121.

Kolmer, C., \& Semetko, H. 2010. International Television News: Germany Compared. Journalism Studies, 11(5), 700-717. http://doi.org/10.1080/1461670X.2010.503020

KPMG. 2015. An Economic Review of the Extent to which the BBC Crowds out Private Sector Activity. A KPMG Report Commissioned by the BBC Trust. BBC Trust. Retrieved from

http://downloads.bbc.co.uk/bbctrust/assets/files/pdf/about/how_we_govern/charter_r eview/annex_b_market_impact.pdf

Krüger, U.M. 2016. Profile Deutsche Fernsehprogramme-Tendenzen der Angebotsentwicklung. Media Perspectiven, 2016(3), 166-185.

Kulturstyrelsen. 2015. Mediernes Udvikling 2015. http://slks.dk/mediernes-udvikling2015/

Lischka, J.A. 2014. Different Revenue Incentives, Different Content? Comparing Economic News Before and During the Financial Crisis in German Public and Commercial News Outlets Over Time. European Journal of Communication, 29(5), 549566. http://doi.org/10.1177/0267323114538851.

Lowrey, W., Brozana, A., \& Mackay, J.B. 2008. Toward a Measure of Community Journalism. Mass Communication and Society, 11(3), 275-299. 
Lund, A.B. (ed.). 2000. Først med det sidste, en nyhedsuge i Danmark. 1. udgave, 1. oplag. Århus: Ajour.

Lund, A.B., Willig, I., \& Blach-Ørsten, M. 2009. Hvor kommer nyhederne fra?, den journalistiske fødekæde i Danmark før og nu. Århus: Ajour.

MDR. 2010. Drei-Stufen-Test Hörfunkprogramme im Internet. Retrieved from:

http://www.mdr.de/mdr-rundfunkrat/drei-stufen-test/beendeteverfahren/artikel88030.html

Meeker, M. 2015. 2015 Internet Trends. Retrieved from: http://www.kpcb.com/internettrends.

Moe, H. 2010. Governing Public Service Broadcasting: 'Public Value Tests' in Different National Contexts. Communication, Culture E Critique, 3, 207-223.

Myndigheten för Radio och TV. 2015. Utveckling och påverkan i allmänhetens tjänst. Retrieved from:

http://www.radioochtv.se/documents/uppdrag/ps\%20marknadsp\%C3\%A5verkan\%20 2014-

2015/utveckling\%20och\%20p\%C3\%A5verkan\%20i\%20allm\%C3\%A4nhetens\%20tj\%C3 \%A4nst\%20inkl\%20summary\%202015.pdf

Newman, N., Levy, D.A.L., \& Nielsen, R.K. 2015. Reuters Institute Digital News Report 2015: Tracking the Future of News. Oxford: Reuters Institute for the Study of Journalism.

Nielsen, R.K. 2015. Local Newspapers as Keystone Media: The Increased Importance of Diminished Newspapers for Local Political Information Environments. In Rasmus Kleis Nielsen, ed., Local Journalism: The Decline of Newspapers and the Rise of Digital Media. London: I.B.Tauris, pp. 51-72.

Nielsen, R. K. \& Sambrook, R. 2016. What is Happening to Television News? Oxford: Reuters Institute for the Study of Journalism.

Norris, P. 2000. A Virtuous Circle: Political Communications in Postindustrial Societies. Cambridge: Cambridge University Press.

Ofcom. 2015a. PSB Annual Report 2015. London: Ofcom.

Ofcom. 2015b. PSB Diversity Research Summary. London: Ofcom.

Oliver \& Ohlbaum, \& Oxera Consulting. 2016. BBC Television, Radio and Online Services: An Assessment of Market Impact and Distinctiveness. Retrieved from:

https://www.gov.uk/government/uploads/system/uploads/attachment_data/file/50401 2/FINAL_-_BBC_market_impact_assessment.pdf

ORF. 2016. Public Social Value. ORF Public Value. 
Pew. 2010. How News Happens: A Study of the News Ecosystem of One American City. Washington, DC: Pew Research Centre.

PwC. 2015. The Impact of a Change in The BBC's Licence Fee Revenue. http://downloads.bbc.co.uk/aboutthebbc/reports/pdf/bbclfpwc2015.pdf

Pfeiffer, C., Windzio, M. \& Kleimann, M. 2005. Media Use and its Impacts on Crime Perception, Sentencing Attitudes and Crime Policy. European Journal of Criminology, 2(3), pp.259-285.

Putnam, R. 2000. Bowling Alone: The Collapse and Revival of American Community. New York: Simon \& Schuster.

Richards, I. 2012. Beyond City Limits: Regional Journalism and Social Capital. Journalism, 14(5), 627-642.

Rogers, J., O'Boyle, N., Preston, P. \& Fehr, F. 2014. The Significance of Small Differences: Cultural Broadcasting and Diversity in Ireland. European Journal of Communication, 29(4), 399-415.

Schmitt, J.B. 2014. Onlinenachrichten und Politisches Wissen bei Jugendlichen. Media Perspektiven, 2014(1), 33-46.

Schmitt-Beck, R. \& Wolsing, A., 2010. European TV Environments and Citizens' Social Trust: Evidence from Multilevel Analyses. Communications, 35(4), pp.461-483.

Sehl, A., Cornia, A. \& Nielsen, R.K. 2016. Public Service News and Digital Media. Oxford: Reuters Institute for the Study of Journalism.

Shehata, A.., Hopmann, D.N., Nord, L. \& Höijer, J. 2015. Television Channel Content Profiles and Differential Knowledge Growth: A Test of the Inadvertent Learning Hypothesis Using Panel Data. Political Communication, 32(3), pp.377-395.

SNF. 2015. Konkurransemessige virkninger av noen utvalgte NRK-tjenester. Retrieved from:

https://www.regjeringen.no/contentassets/edf33dfdbb1d425891ec37c2c8087bd7/nrkrapport-mars2015.pdf.

Soroka, S., Andrew, B., Aalberg, T., et al. 2013. Auntie Knows Best? Public Broadcasters and Current Affairs Knowledge. British Journal of Political Science, 43(4), pp.719-739.

Stamm, K.R. 1985. Newspaper Use and Community Ties: Towards a Dynamic Theory. Norwood, NJ: Ablex. 
Strabac, Z., Thorbjørnsrud, K. \& Jenssen, A.T. 2012. News Consumption and Public Opposition to Immigration across Countries. In T. Aalberg \& J. Curran, eds. How Media Inform Democracy: A Comparative Approach. New York: Routledge, pp. 176-188.

Strömbäck, J. 2016. Does Public Service TV and the Intensity of the Political Information Environment Matter? Journalism Studies, Online first. doi: 10.1080/1461670X.2015.1133253

Swedish Media Commission. 2016. De offentligt finansierade medierna-frågeställningar som bör utredas inför nästa tillståndsperiod. Retrieved from:

http://www.regeringen.se/contentassets/f5a50b115b824ee08ba1847477ea5dba/ku201600767-1-pm-om-de-offentligt-finansierade-medierna-23-mars-2016-pdf2570955_1_1.pdf

Tiffen, R., Jones, P.K., Rowe, D., et al. 2014. Sources in the News: A Comparative Study. Journalism Studies, 15(4), 374-391. http://doi.org/10.1080/1461670X.2013.831239 van der Wurff, R. 2005. Competition, Concentration and Diversity in European Television Markets. Journal of Cultural Economics, 29(4), 249-275.

Waldfogel, J. 2011. Station Ownership and the Provision and Consumption of Radio News. Retrieved from: https://apps.fcc.gov/edocs_public/attachmatch/DOC-307470A1.pdf Weberling, J. 2011. Mapping Digital Media. Case Study: German Public Service Broadcasting And Online Activity. Open Society Foundations. Retrieved from: https:/ / www.opensocietyfoundations.org/sites/default/files/mapping-digitalmedia-german-psb-online-activity-20111018.pdf

Woldt, R. 2011. Öffentlich-rechtliche Onlineangebote: Keine Gefahr für den Wettbewerb. Erkenntnisse aus den Marktgutachten im Rahmen der Drei-StufenTests. Media Perspektiven, 2011(2), 66-79.

Zubayr, C., \& Geese, S. 2013. Die Informationsqualitait der Fernsehnachrichten aus Zuschauersicht. Media Perspectiven, 2013(6), 322-338. 


\section{About the authors}

\section{Dr Rasmus Kleis Nielsen}

Rasmus Kleis Nielsen is Director of Research at the RISJ and serves as Editor in Chief of the International Journal of Press / Politics. His work focuses on changes in the news media, on political communication, and the role of digital technologies in both. In the last 5 years he has published 5 books and more than 30 other publications dealing with these issues. In 2014, he won the Doris Graber Award for best book on political communication published in the last 10 years, awarded by the American Political Science Association, for his book Ground Wars. He is also a recipient of the 2014 Tietgen Prize for his work on current changes in the news media. Dr Nielsen has taught courses on political communication, news media, and journalism at Oxford, and previously courses on European politics and international relations at Columbia University, Ludwig Maximilian University Munich, the University of Copenhagen, and Roskilde University. He gives frequent presentations at academic conferences and industry events, and his work has been covered by a range of news media including the BBC, The Economist, the Financial Times, the Guardian, and various other international media. He serves as a member of the editorial boards of Digital Journalism, the Journal of Information Technology \& Politics and Social Media + Society.

\section{Dr Richard Fletcher}

Richard Fletcher is a research fellow at the RISJ. He is primarily working on global trends in digital news consumption, the use of social media by journalists and news organisations, and more broadly, the relationship between computer-based technologies and journalism. Dr Fletcher has authored a report to supplement the 2015 Reuters Institute Digital News Report and is the lead researcher on the forthcoming 2016 edition of the Digital News Report (working closely with the lead author, Nic Newman). He was previously a junior research fellow in the Department of Journalism at City University London. Here he worked on the development and evaluation of SocialSensor, a tool designed to allow journalists to collect, process, and aggregate large streams of social media data in order to discover trends, events, influencers, and interesting media content. More recently, Dr Fletcher has also been engaged in research surrounding the 2015 UK General Election - with a focus on both using social media data to generate predictions, and on understanding the differences between how elections are discussed in the mainstream media and on social networks. His original undergraduate and employment background was in computer science. Since then he has completed an MSc in science, medicine, 
technology and society from Imperial College London and a $\mathrm{PhD}$ in sociology from the University of Surrey.

\section{Dr Annika Sehl}

Annika Sehl is a research fellow at the RISJ. Her work is part of a larger project aimed at analysing media developments in a sample of more than 20 European countries, with a particular emphasis on digital media, news, and politics. Her primary focus is on how public service media and state-owned media are developing across the countries covered. Her research interests include journalism, comparative research, audience research and research methods. Dr Sehl comes from a position as postdoctoral researcher at the Institute of Journalism, TU Dortmund, Germany, where she also acquired her PhD (with distinction). Furthermore, she has been a visiting professor of communication studies at the University of Hamburg. She holds a diploma (with distinction) in journalism from TU Dortmund and spent an Erasmus semester at the University of Gothenburg. She has taught at a range of German universities as well as at the University of Gothenburg, the University of Ghent, and the Lomonossov University in Moscow. In addition to her academic experience, Dr Sehl trained as a journalist with the news broadcaster N24 in Berlin, Hamburg and Munich, and has worked as a journalist in Germany and abroad including in the German Television's (ARD) studio in New York, the Namibian Broadcasting Corporation (NBC) in Windhoek and the German Press Agency (DPA) office in London.

\section{Dr David Levy}

David Levy has been Director of the RISJ since September 2008. As well as covering the full range of issues around developments in journalism he has particular expertise in public service broadcasting, media regulation and the interaction between digital technology and media regulation both within the United Kingdom and in Europe. Before joining the Institute he was Controller, Public Policy at the BBC until 2007 where he led the BBC's policy for the charter review and was in charge of public policy and regulation. Prior to his BBC policy role he worked as a journalist, first for the BBC World Service and then for BBC News and Current Affairs; as a radio producer and reporter on File on 4; as a TV reporter on Newsnight, and as editor of Analysis on Radio 4. He was a visiting professor at Sciences Po in Paris from April to June 2012 and in 2008 served as the sole foreign member of the French Commission established by President Sarkozy to review the future of the French public service broadcaster, France Télévisions. He was a board member of the French international broadcaster, France 24, between 2009 and 2012. He has been a non-executive member of the UK Statistics Authority since July 2012 and of the Content Board of the UK Communications Regulator Ofcom since 2011. 